\title{
Property Rights versus "Public Necessity": A Perspective on Emergency Powers and the Supreme Court*
}

\section{HARRY N. SCHEIBER}

Chief Justice Earl Warren once wrote that a free government is continuously "on trial for its life." 1 And never are the foundations of constitutional liberties more fragile than in periods of emergency, when government invokes extraordinary powers. Invariably, emergency powers involve the immediate curtailment of some rights; at their extreme in martial law, they can warrant an entire suspension of normal civilian governmental functions, as well as full suspension of dueprocess guarantees. ${ }^{2}$ Once the constitutional fabric has been stretched to accommodate urgent public necessity in such situations, moreover, restoration to its earlier condition is not automatic or inevitable. On the contrary, as Justice Robert Jackson presciently warned, once the Supreme Court validates as constitutional the abridgement of essential rights during an emergency-and especially when the Court does so in relation to "the vague, undefined and undefinable "war power" - any principle that is thus articulated to justify such emergency action "then lies about like a loaded weapon ready for the hand of any authority that can bring forward a plausible claim of an urgent need." 3

The history of American law since the 1940s indicates that Jackson had it right. There has been a steady expansion of discretionary presidential emergency powers, and a consequent weakening of congressional authority in this regard. And the judiciary has largely acquiesced in this process - indeed, in some respects it has advanced it. ${ }^{4}$
Even so, the history of the last few decades does not tell the whole story. The present-day content of classic Fifth Amendment guarantees of life, liberty, and property has been shaped in vital ways over the course of two centuries by the constitutional jurisprudence that came out of successive military and peacetime emergencies. Understandably enough, it is "life" and 


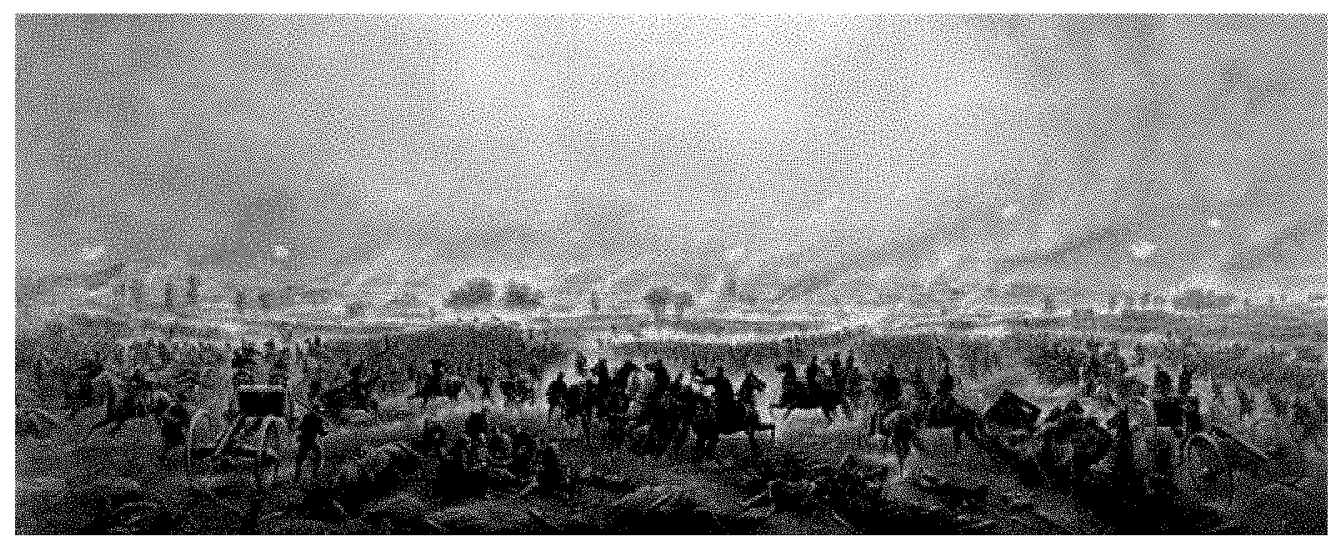

Although the Civil War cases involving emergency war powers get more attention, many important cases from that era bore directly on government confiscation and property rights.

"liberty" rather than "property" that immediately come to mind when one thinks of the crises in which the exercise of the war powers or other extraordinary government powers have had the greatest impact. The due-process questions raised by the use of martial law in the Civil War and in World War II, the severe repression of First Amendment freedoms during World War I, and the systematic prosecution of dissenters against the war policy during the Vietnam conflict are all well known and well studied. ${ }^{5}$ The present study, however, has a different focus. I am concerned here with the problem of how property rights - the third element in the "life, liberty, property" triad-have figured in American constitutional law in varied situations in which emergency powers were mobilized. Several distinctive types of events are included in the scope of the discussion: (1) periods of declared war; (2) periods of armed conflict without formal congressional declaration of war, of which there have been many, dating from the campaign against the Barbary pirates and down to the present day and the socalled war on terrorism; (3) crises stemming from fire or natural disasters in peacetime; and (4), uniquely important from the standpoint of property rights, periods of economic crisis, most especially the New Deal years of the 1930 s depression, when a great deal of the present-day constitutional and statutory appa- ratus of emergency powers was first laid in place.

Some general aspects of the propertyrights nexus with emergency powers require some attention before proceeding to the specifics of the Supreme Court's history on this matter:

\section{Even in the highest moments of drama in} the government's denial of basic rights during emergencies, property rights may be at issue, albeit only below the surface or as a secondary consequence.

Consider what is today quite universally regarded, in retrospect, as the indefensible action of the government during World War II in subjecting tens of thousands of Japanese Americans-citizens as well as aliens-to arbitrary removal from their homes and a long period of internment under armed guard in the internment centers located in bleak and desolate locations in the western United States. ${ }^{6} \mathrm{We}$ do not think immediately of property rights as part of the suffering that ensued. But property losses were an important dimension of the policy. To illustrate: In one roundup of Japanese Americans immediately after Pearl Harbor, the Federal Bureau of Investigation and military 


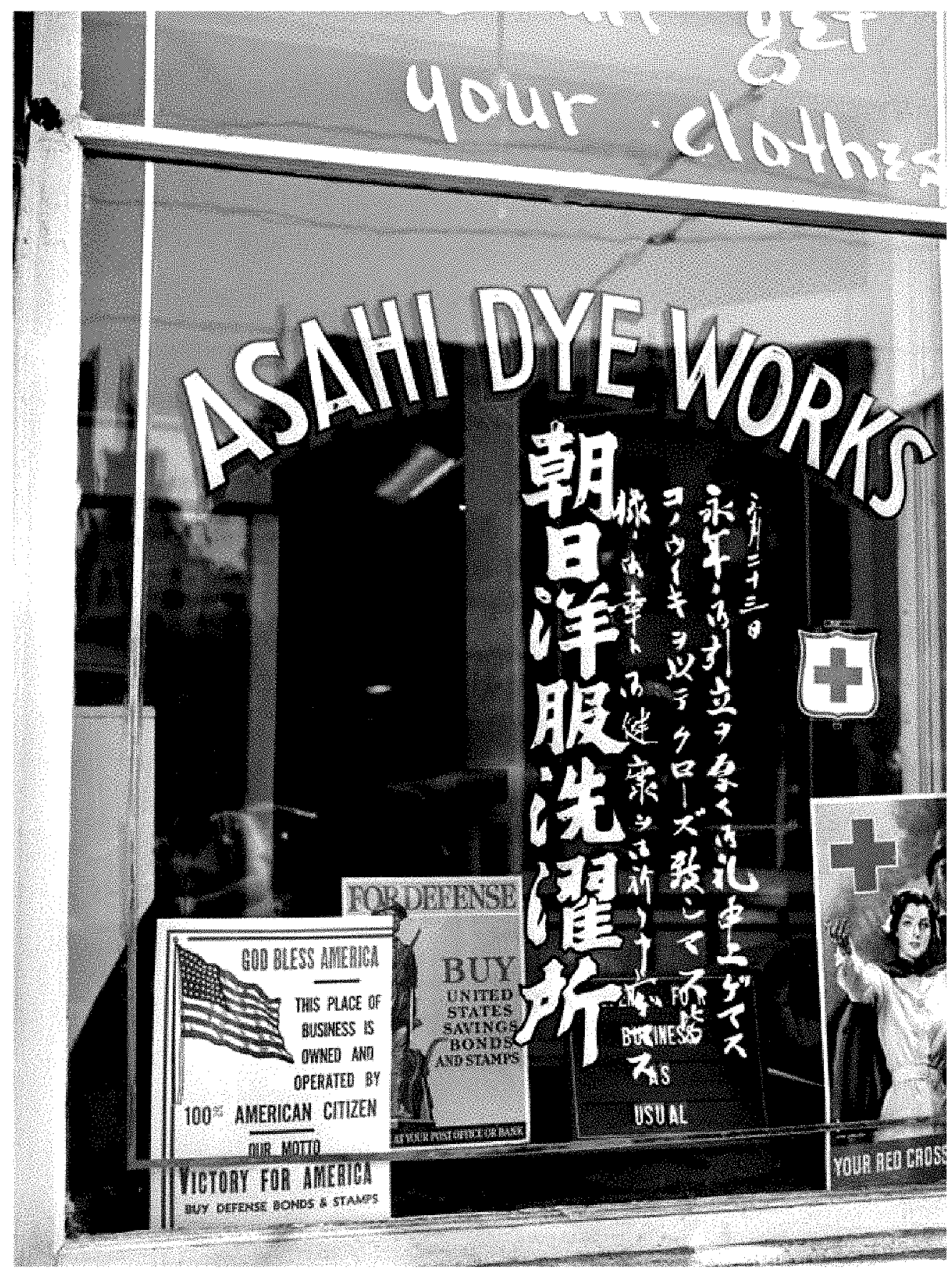

Properties left behind by Japanese-American internees, such as this San Francisco laundry, were turned over to the Federal Reserve Bank in San Francisco, an agency ill prepared and lacking the expertise (and perhaps the integrity) to guard their interests. In disposing of the property while the internees were absent, the bank probably realized only a tenth or less of market value on behalf of the owners. 
officers in charge of detention distributed to each of the prisoners a document entitled “Citizen Detention Questionnaire," which read as follows:

We know that you are inconvenienced. However, we ask that you recognize our problem [and that] our job is not pleasant in this regard.

We know that your being detained leaves some of your property, particularly real property, unguarded. It is our desire to protect every bit of your property pending your detention.... Some of you will immediately believe that this is a ruse to make you divulge your holdings in order that the government might take possession of the same. While the government might do that, it could do the same without the aid of any information that you might give it. THIS QUESTIONNAIRE HAS BEEN PUT UP IN ORDER THAT WE MAY BE BETTER ABLE TO PROTECT YOUR PROPERTY. ${ }^{7}$

To the vast majority of the internees, the promises of benevolence with respect to their property rights proved to be almost completely meaningless. The photographic record tells the story of how, notoriously, farmland and homes were thrown onto the market at any price the owner could obtain before families were herded into buses and trains for removal to the distant campus; or how returnees came back at the end of the war to find their businesses or other properties trashed or taken over illicitly. Property left behind by the Japanese Americans on the West Coast was turned over to the Federal Reserve Bank in San Francisco, an agency ill prepared and lacking the expertise (and perhaps the integrity, in the circumstances) to guard the interests of the internees. The federal official who headed the administration of internment would estimate that in disposing of the property while the internees were absent, the Federal Reserve Bank proba- bly realized only a tenth or less of market value on behalf of the owners. ${ }^{8}$

This episode serves as a vivid reminder that when civil liberties are suspended and normal due process is not allowed to persons incarcerated for whatever "emergency" reasons government puts forth to justify its actions, there is inevitably an immediate economic impact on such persons and their families and/or jobs or business affairs. It is similarly the case with the burden of legal expenses when persons are caught in the toils of the law, whether involving criminal prosecutions or civil claims, stemming from "emergency" measures against them. This constitutes an important dimension, in very human terms, of how "the great rights" under pressure in emergencies implicate economic interests of the persons, groups, or organizations who are the target of government actions. ${ }^{9}$

2. Many of the leading cases in which the federal courts have confronted the issue of emergency powers have been cases primarily concerned, however, with seizure or uses of private property, rather than with incarceration or restraint of persons.

Again, the pictorial record serves as a reminder as to this dimension of history, exemplified in the photograph (used as an illustration in many history textbooks) of the Montgomery Ward Company's president, Sewell Avery, being forcefully carried out of his office in 1944 by helmeted soldiers-with the U.S. Attorney General present in person to oversee Avery's ejection. This operation was carried out in response to Avery's refusal to accept War Labor Board emergency regulations that guaranteed certain labor-union rights, leading to a government takeover of Montgomery Ward by the government. ${ }^{10}$

Of course, the ramifications of that episode and of the several cases in the Supreme Court directly involving individual or corporate property-rights issues, as they will be discussed in this study, extended far beyond the specific property questions at the bar. In most 


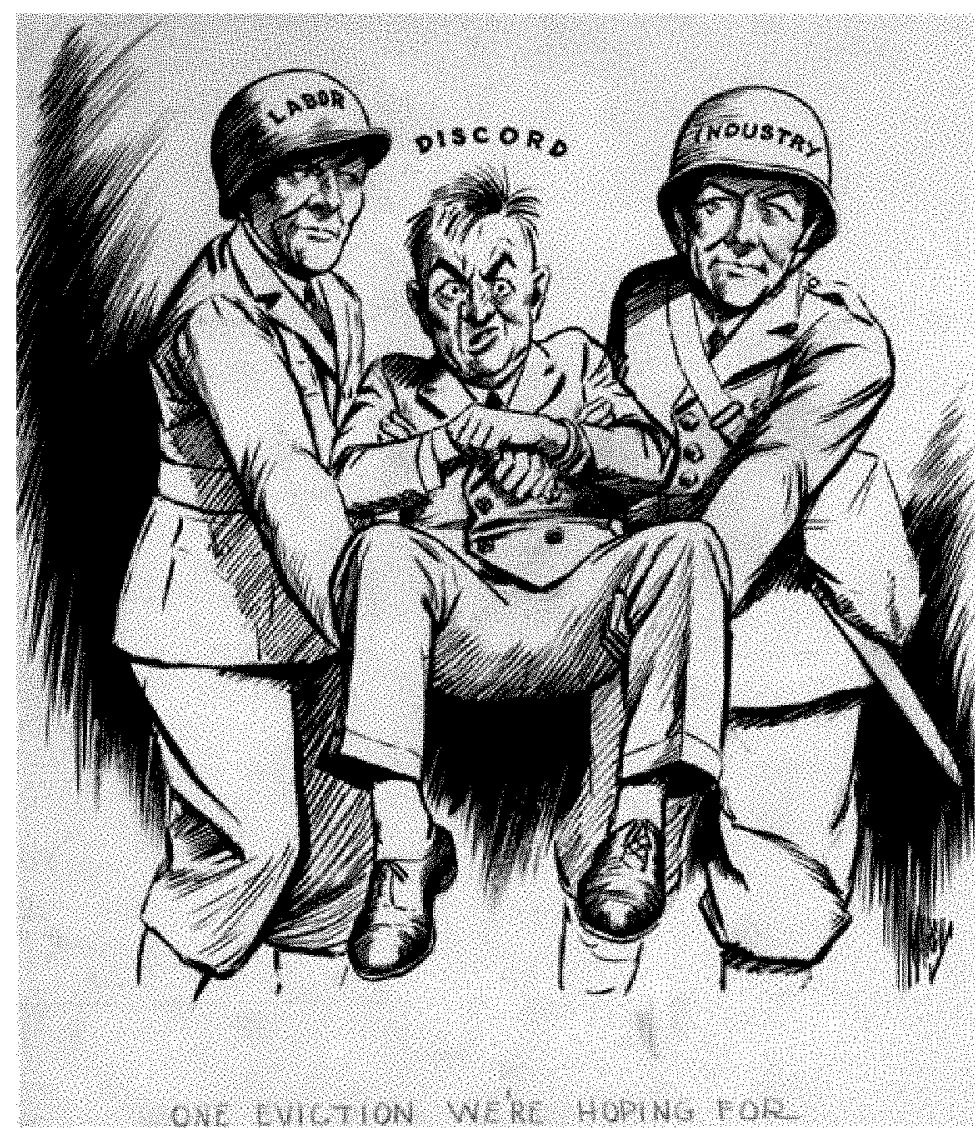

In 1944, after the Montgomery Ward Company failed to obey a government order to hold fair union elections, the government took over the executive offices, and when the company chairman, Sewell Avery, refused to leave, soldiers carried him out. This cartoon parodies the famous photograph of the eviction and urges greater cooperation between industry and labor during World War II. of these cases, two opposed "age-old, timehonored principles of law... [met] head-on in conflict." 11 Those principles were the doctrines of vested property rights on the one side, and, on the other, the claims of "necessity" advanced by the government, whether under the umbrella of the war powers or in a peacetime crisis context. It was the doctrinal resolution of these cases, however, that counted in these instances. That is to say, although property rights may have been the immediate issues before the courts, it was the expanding scope of emergency powers in the generic sense that had an impact extending far beyond property rights and into the crucial domains of law regulating the guarantees of "life and liberty."

\section{American constitutional doctrine re-} garding emergency powers and property rights in the United States is grounded in a long and complex history in AngloAmerican law regarding the scope of government authority, both in domestic crises and in wartime.

The doctrines of taxation, eminent domain, and police power have been in a constant situation of tension with the basic guarantee of "vested rights" throughout the full course of American legal history. Courts have constantly reappraised and redefined private rights in the light of successive challenges based on changing circumstances, public needs as expressed in legislation and litigative claims, and, above all, a time-honored concept of "public rights" as a validating canon for governmental interventions that trench on private property claims. $^{12}$

Thus, the very foundations of emergency powers more generally are rooted deeply in 
legal and jurisprudential concepts that had property rights as a major focus. Both in English common law and in the doctrines of international law, long predating the founding of the United States as an independent nation, juridical writers and the courts had much to say about property in relation to emergency powers. For example, in the history of how the eminentdomain power was formulated and applied by American state courts in the early nineteenth century, judges relied to a very great extent upon Vattel, Pufendorf, Binkershoek, Grotius and other writers of the continental natural-law and civil-law schools for the basic concepts of both positive state power and its limitations in regard to property rights. ${ }^{13}$ When considering more generally municipal law and the proper limits of sovereign power in the nation-state, the civil-law writers gave extensive attention to the problem of property rights in relation to "public necessity." They sought to define the boundaries that separate private property rights and the claims of the sovereign (which, in the common-law courts and treatises, became also the claims of the public); and they developed a classification of conditions under which property could properly be seized or damaged by government, and with what requirements for compensability. These writers asserted that such extraordinary powers could legitimately be used for the public welfarefor salus populi-and not just for the narrow interests of sovereign itself. The doctrine of salus populi was invoked specifically as validating government's trenching on ordinary property rights in the face of potentially mortal crises, including epidemics, fires, safety hazards, and other peacetime emergenciesnot only in war. ${ }^{14}$ In these "times of necessity," or "times of exigencies," as such crises were described, there were few limits on the sovereign's authority to act quickly and decisively. ${ }^{15}$

Much the same line of doctrine was to be found in the English courts and in AngloAmerican treatises on the common law. A long history of precedent in the common-law courts on private torts provided a robust doctrinal reinforcement for rules that immunized public officials from individual liability in emergencies that threatened the public good. ${ }^{16}$ With few exceptions, the American state courts accepted English precedent in regard to emergencies such as fire, ruling that it was lawful for government officers to raze houses to the ground in order to prevent the spread of flames to nearby woods or structures. The judges thus systematically applied the rationale of "necessity" to rationalize takings without compulsory compensation to property owners in emergencies of this sort. ${ }^{17}$ Similarly, in the nineteenth century, the claims of "public necessity"or even of merely "the expedience of the state"18_as a parallel to "emergency" claims were advanced to warrant a major expansion of the legitimacy of eminent-domain takings for a variety of uses..$^{19}$ It was a matter for the legislature to decide whether to compensate for losses suffered by property owners, and if so at what level. ${ }^{20}$

The claims of the public and its welfare similarly were prominent in the common law of waterways, with writers beginning with Lord Matthew Hale contending for a classification of shoreline waters, navigable waters, and waters privately owned by "affected with a public interest"- a concept imported into American constitutional law first in the law of waters and then, most famously, in the Munn case in 1877 , with its enormous impact on constitutional doctrine for more than half a century thereafter. $^{21}$

Destruction of property by military or other officials in wartime to prevent equipment, supplies, or structures from falling into the hands of the enemy or in order to impede enemy troop movements was viewed from the same perspective by the law writers and in the precedents from the English courts. That is, they defined the natural rights of the sovereign as including, above all, the right —and, indeed, obligation—of seeing to 
the self-preservation of the state and to salus populi. Moreover, there was a hard pragmatic aspect to the doctrines warranting takings and damages to property in wartime-namely, that if governments were to be held strictly liable for monetary damages for property destroyed during military operations, it would likely produce bankruptcy of the national treasury. ${ }^{22}$

4. An important element of the doctrinal legacy from the civil-law and natural-law writers, in influencing American property and emergency-powers law, was the jurisprudence of "the law of nations."

In their writings on international law, then termed "the law of nations," the civil lawyers and natural-law writers sought to identify moral principles that might underpin rules of law that would restrain the actions of sovereigns in wartime, although they conceded that such restraints were a matter of the sovereign's own grace, accepted in the interests of humane considerations. Their theories on these matters were motivated in part, too, by a desire to protect property rights in commerce, especially in cases in which the cargoes of vessels captured on the high seas or in port were taken as prizes by warships or privateers. These writers also addressed the question of the status of foreign merchants and their property in inventories held in countries that suddenly were at war with the nation of their own citizenship. In their arguments defending such rights against arbitrary action of the host government once war broke out, the civil-law writers showed a great solicitude for the property rights of alien enemies caught by the outbreak of hostilities. Their justification for such solicitude was in part a practical one, based on considerations of how retaliation in the event of arbitrary seizures might escalate such harms, and also on considerations of how lack of comity in such situations might be detrimental more generally to the interests of the commerce so vital in the economy of the early nation-states and their mercantilist empires. $^{23}$

As was true of the doctrinal heritage of civil and common law in the general realm of property rights versus public needs, the law of nations, too, would play a major part in shaping the U.S. Supreme Court's jurisprudence of emergency powers. The relationship of accepted principles of international law to the enumerated powers and to the war power was a major preoccupation of the Marshall Court in the first decades of the nineteenth century, as will be discussed further below. The basic problem of how that relationship should be defined in light of modern developments in international law and evolving consciousness of human rights remained a prominent issue in our law in subsequent eras of American history. ${ }^{24}$ Indeed, the debate persists in full vigor to our own day. ${ }^{25}$

The varied interwoven configurations of property-law doctrine and the emergency power in American constitutional law came at first largely from tests of the war power in the nineteenth century. Without restricting myself to landmark cases, and without pretending to touch on all the landmark decisions, I would like to discuss three types of cases that were of particular importance from the Republic's beginnings to the Reconstruction era. First was a pair of Marshall Court decisions on property issues that arose from America's confrontations with France and Great Britain that culminated in the War of 1812 . Then I will turn to a landmark case on individual liability of military officers in the field, originating from an incident in the War with Mexico. Two cases from the Civil War era will be considered. I will conclude my analysis with a brief examination of some twentieth-century developments that have elaborated and, to a great degree, transformed 


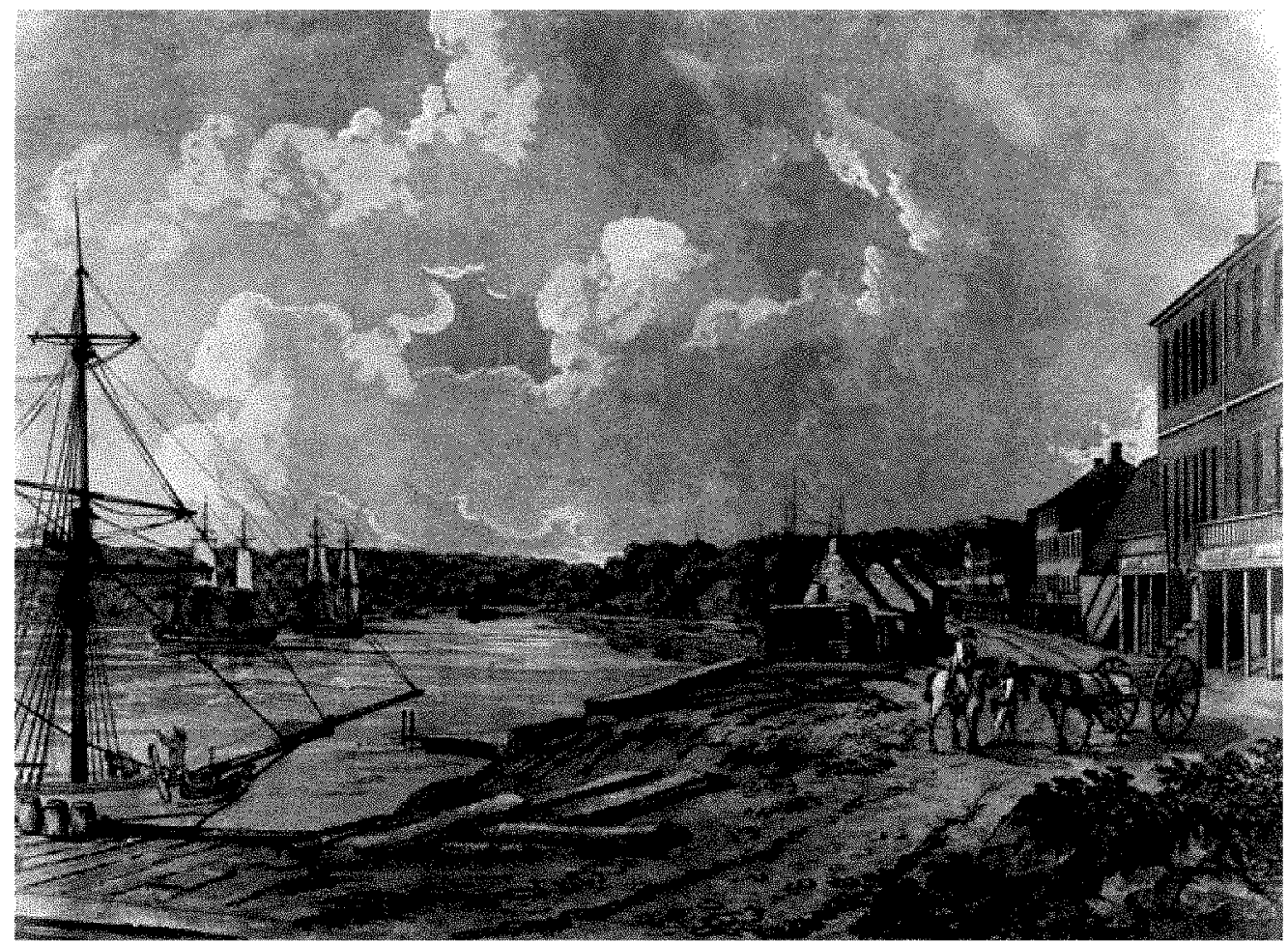

Although the United States never formally declared war on France, it did suspend commercial intercourse between the two countries in 1799 and authorize the President to stop any American ship on the high seas suspected of carrying cargo to France or its dependencies, including those in the West Indies. An American captain who captured a prize ship returning from the French islands was found to have done so illegally by the Supreme Court in $\mathbf{1 8 0 4}$, but his indemnification was later paid by Congress.

the heritage from the previous eras of constitutional law.

\section{Marshall Court Decisions on Prizes and Confiscation of Enemy Property}

Two decisions of the Marshall Court will illustrate a few vitally important aspects of its jurisprudence in the early years of the Republic.

In the case of Little v. Barreme, decided in 1804, the Court confronted the highly interesting question of what roles Congress and the Executive played, respectively, in fashioning emergency policies in a situation of "imperfect" war. ${ }^{26}$ The Court adopted this last phrase because the situation involved hostilities against France in the absence of a war declaration, the specific legislation at issue before them being the act of February 1799 suspend- ing commercial intercourse between France and the United States. In coming to its decision, however, the Court also ruled on what the personal liabilities were of the American naval officer who was found to have acted outside the law in an action on the high seas.

The statute had authorized the President to stop and examine all American flagships on the high seas suspected of carrying cargoes to any port in France or any of its dependencies, including the West Indies island possessions that were so important as a market for American mainland producers in that era. The crux of the Court's decision was that when Congress specifically authorized such an action (involving cargoes en route to specified ports), it was not open to the President to instruct naval commanders (as he did in official orders implementing the act) to interdict cargoes en route "to or from" French ports. 
The cargo vessel in question had been boarded and seized by the U.S. Navy brigantine Boston, commanded by Captain Little. He brought the prize vessel into Boston for judgment and condemnation, and the district court initially ruled that it had been a lawful capture and thus validated the prize. On appeal, the vessel was determined to be Danish (despite suspicious circumstances that gave credence to Captain Little's conclusion that it was American). For the Marshall Court, however, the key issue had to do with the President's instructions and their legality. In his opinion for the Court, Chief Justice John Marshall found that there was no justification for a finding that the vessel was bound to a French port; rather, it was clearly proceeding from the French islands. Hence, its capture was illegal under the terms of the statute. On this finding, the Court held Captain Little personally liable for all damages to the owners' interests with respect to capture, detention, and value of cargo. It was a harsh judgment, and it obviously pained Marshall greatly. He expressed eloquently his personal sympathy for the plight of an officer engaged in a military operation of this sort, with all its dangers, and in light of "that implicit obedience which military men usually pay to their orders of their superiors, which indeed is indispensably necessary to every military system." Yet he had become convinced, Marshall wrote, "that the instructions cannot change the nature of the transaction, or legalize an act which without those instructions would have been a plain trespass." 27

The Court's assertion in this case of congressional power to specify limits-even only implicitly, in this instance, on presidential war powers-was fated to become a lightning rod for constitutional controversy in every war or war-related emergency from that day to our own. The Barreme case is remembered best for that reason, and for the way in which the Court advanced its institutional campaign to exercise jurisdiction and to maintain its posture in defense of the rule of law at a time of inflamed public opinion.$^{28}$ But I would like to dwell for a moment on the consequence for Captain Little and others who found themselves in a position similar to his in subsequent years. Both civilian officials in emergencies of all kind and military and naval officers in war situations are forced to depend - as was this naval captainon the generosity of the legislature after the fact to relieve them of the personal obligation to pay indemnification in cases in which their actions are challenged in private suits and found, in retrospect, to have been illegal. It is sometimes said that for military and other officials in a similar position, the possibility of being held personally liable after the fact can serve as a source of restraint - as an effective check, as it were, on the exercise of arbitrary power. That is, the officer has to calculate whether the emergency action is clearly enough justified by explicit law, or at least by what evidence of authentic "urgent necessity" might be adduced afterward to justify the action taken. ${ }^{29}$

The extent to which such a check is truly effective in reducing the possibility of unwarranted action is a matter of speculation, and certainly individual personality will play a part in a specific situation. One can hardly doubt that Captain Little-who, in fact, did win relief later from Congress-would have believed that the Court had acted unwisely in not extending the cloak of immunity to him in the circumstances precisely because the Court's doctrine might serve to instill excessive caution in commanders, or even subject them and the country to harms that speedy and forceful action could have headed off.

As our Mexican War case of Harmony v. Mitchell reveals, the problem persisted for the military leadership of the country in later years. ${ }^{30}$ Indeed, even a century after the Mexican War, the indemnification question plagued the commanders who had been in charge of martial law in Hawaii during World War II, as postwar private indemnification suits followed as soon as the Supreme Court ruled the regime to have been unconstitutional. The generals and other military and 


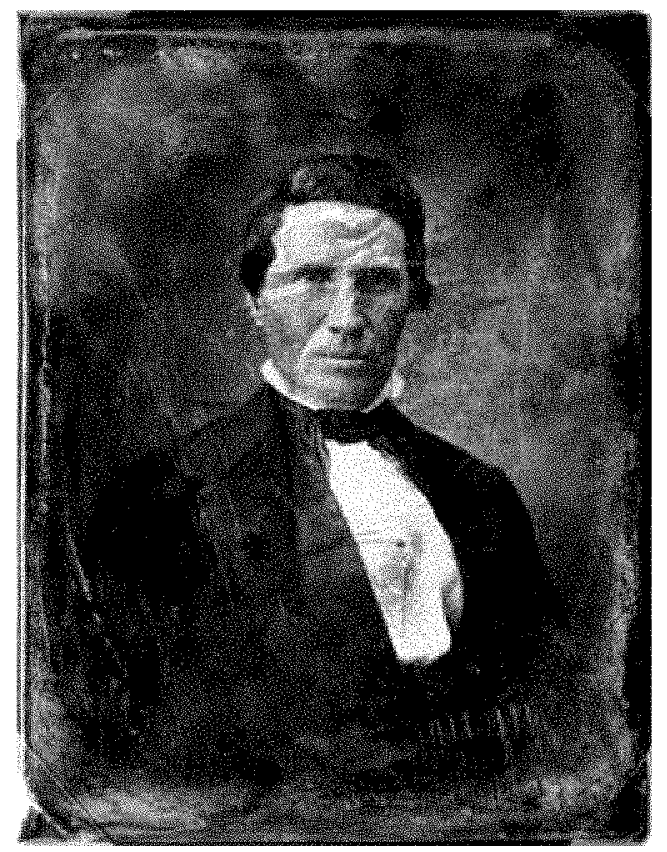

During the Mexican War, U.S. Army Colonel Alexander William Doniphan (pictured) ordered the seizure of merchandise (pulled by a train of mules with wagons) valued at U.S. $\$ 90,000$ from Manuel Harmony, a naturalized American citizen who had developed a lucrative business trading with U.S. Army forces during their southward march into Mexico. Doniphan justified the seizure of goods, animals, and wagons as being necessary for his troops on their long march to Chihuahua and so that Harmony would not sell to the enemy.

civil officials who were being sued personally complained of inadequate legal support and promise of financial backing from the War Department, predicting that if they were not given such backing, no commander in a future war would risk fortune and reputation by moving resolutely (as they believed they had done) to do what they deemed necessary. Unlike Chief Justice Marshall, the federal trial judge who presided over the generals' trial in Hawaii instructed the jury that a respondeat superior defense was sufficient, so that even if the generals had exceeded their constitutional authority, if they had "exercised reasonable judgment in good faith, under the circumstances as [they] saw them at the time," they could not be held liable. Consequently, unlike Captain Little, the World War II generals did not have to look to Congress to make them whole financially after enduring an extended period of litigation in the civil courts. ${ }^{31}$

Brown v. U.S., decided in 1814 , is the other Marshall Court case to be considered here in which the Justices' understanding of the law of nations, together with its applicability in the American constitutional context, became a determinative factor in adjudication of emergency powers. Brown was a property case in that it involved the claims of legal ownership to a cargo of timber and lumber products originally loaded at a Georgia harbor and then taken to New Bedford, Massachusetts for safekeeping when the war with Britain broke out. ${ }^{32}$ There it was unloaded, with some of it held on the wharfs but the timber floated on a nearby creek for safekeeping. It was subsequently seized as being enemy-owned and therefore subject to the embargo against Great Britain during the War of 1812. An informer who stood to gain from the proceeds of condemnation reported the location of the property, and the government moved to seize it. The entire legal question in the Supreme Court appeal turned on the law of nations and its rules, pertaining to whether a sovereign at war had the authority to seize property in this status when it was held on land as opposed to seizure of the property of enemy aliens taken as a prize at sea.

In the Court's majority opinion, Chief Justice Marshall conceded that under the executive war power, the President might legitimately order confiscation of enemy-owned property on any terms. But in that respect, "the will" must be express, with no implication from silence that such a discretionary power was intended to be effective, or else there must be a specific act of Congress authorizing confiscations of particular kinds. Lacking such express intent, Marshall ruled, the law of nations would provide the basis for adjudication. That law provided for "mitigations of this rigid rule" of the sovereign's plenary authority over enemy persons and property in wartime, mandating "the humane and wise policy of modern times" that provided immunity from seizure for 
enemy property on land. ${ }^{33}$ Marshall offered an excursus into the writings of Vattel, Chitty, and other sources of the law of nations. He also cited the traditional view taken by British admiralty courts, admitting that they were not following the humane rule themselves in the present war, since they had taken American property similarly situated on their soil. The depth of Marshall's commitment to international law was evidenced in his response to that fact. If English admiralty courts "have done wrong, and proceeded against the modern law of nations in these cases," he wrote, "this honorable Court will not, for that reason, adopt so unjust a practice." 34

This was one of those rare occasions on which the Marshall Court was bitterly split, as Justice Joseph Story-whose decision in circuit court was overturned in this casereprinted verbatim his lengthy opinion from the circuit case, presenting an entirely different interpretation of the law-of-nations heritage and insisting upon the need for application of English admiralty precedent. To this he appended a strident declaration of the implicit or inherent powers of the President, buttressed by a Hamiltonian-style exposition on the Necessary and Proper Clause as relevant to the conduct of war. ${ }^{35}$ From a property case, then, emerged a framework for continuing debate of vital constitutional questions of much larger import. As it had done in other decisions as well, in this case the Marshall Court laid out here the basic framework of future constitutional controversies. It did so, moreover, in specific terms that remain strikingly familiar to us as we deal with issues of our own day raised by the "war on terrorism" and more generally by the modern "National Security Constitution." $" 36$

\section{2. "Military Necessity," Judicial Review, and Personal Liability: The Mexican War Trader's Case}

The Marshall Court's decisions supporting private rights in relation to the war power in these early cases found echoes in a decision, Mitchell v. Harmony, that arose during the war with Mexico and involved the property claims of Manuel Harmony, a naturalized American citizen. ${ }^{37}$ Harmony was a trader in the western territories who decided to follow behind the U.S. Army forces on the famous march southward into the heart of Mexico under the command of Colonel A. W. Doniphan. With a train of mules and with wagons and merchandise valued at U.S. $\$ 90,000$ or more, Harmony apparently did well selling to settlers along the route and probably to the Army as well. At a moment when the march had reached an admittedly dangerous region far from the base of their force or in reach of reinforcements, Doniphan ordered the column to move on to Chihuahua, some 300 miles farther into the interior. Harmony decided the risk was too great to warrant continuing, and he prepared to pull out. On Doniphan's orders, Colonel Mitchell, the officer directly in charge, then seized Harmony's entire stock of goods, together with wagons and animals, for use of Mitchell's troops - but also, as he would claim later, to assure that Harmony would not trade with the enemy. Following the war, Harmony sued Mitchell personally for restitution. In a remarkable, almost strident, charge to the jury, the trial judge put his own spin on the facts (including a statement to effect that the long march on Chihuahua, though it proved a military triumph in the end, seemed close to folly when it was ordered), and he virtually instructed the jury to find for Harmony. And so it did, with an appeal taken to the federal courts immediately by the colonel.

Chief Justice Roger Taney wrote the opinion for the Supreme Court in 1851, finding for Harmony and ordering Mitchell to pay full damages and interest. Taney's position reflected and advanced the rule on illegal instructions that Marshall had stated in Barreme. Property rights were to be respected, Taney averred, no matter what a military officer's "zeal for the honor and interest of his 
country... in the excitement of military operations." In what would become an explicit standard on which future courts would rely in reviewing not only property takings but other executive actions in wartime, Taney wrote that to justify seizure, "the danger must be immediate and impending; or the necessity urgent for the public service, such as will not admit of delay..... Every case must depend on its own circumstances. It is the emergency that gives the right, and the emergency must be shown to exist before the taking can be justified." 38 The burden of proving that a qualifying emergency had existed fell upon the officer in command; and it would then be "for a jury to say" whether the suspension of private rights for "the common and public good" had been justified. ${ }^{39}$ Relying, one must assume, on the New York trial judge's characterization of the Chihuahua march, Taney found that Mitchell had taken Harmony's property in order to support "a distant and hazardous expedition" in an aggressive action; the commander was not seeking to defend his troops in the face of an impending attack by the enemy. In such circumstances, Taney declared, "[We] think it very clear that the law does not permit it." 40

Apart from implanting the potent language about "danger...immediate and impending" as a justification for emergency actions, Taney also reinforced the Marshall Court's position that asserted the power of judicial review. Most important of all for future adjudication, the Court reserved to the judiciary and normal judicial process the authority to reach a final judgment as to whether a government action was supported by the claim of "necessity." If "it is the emergency that gives the right," it would be the Court that would establish whether the emergency, as a prior condition, actually existed in fact. "Necessity" was at the crux of the inquiry as to constitutionality. On that crucial element in emergencypower law, the Court was unwavering, whether in the hands of Federalists or those of their Jacksonian succession. ${ }^{41}$

\section{Confiscation, Compensation, and Emergency Powers: The Civil War Crisis}

In the standard constitutional account of emergency powers, the Civil War era is remembered best, understandably enough, for the landmark postwar decision in Ex parte Milligan. ${ }^{42}$ The Court's split-opinion ruling in Milligan went by a narrow majority against the government and declared that constitutional rights must be respected in wartime emergency situations unless there were conditions of actual, not merely anticipated, invasion - a reiteration of the Taney Court rule from Harmony - and, further, unless the civilian courts were closed and unable to function. So would the law stand on the question of martial law for the next eighty years, until World War II. ${ }^{43}$

As crucially important as Milligan is in the history of emergency powers, there were also important cases from that era that bore directly upon property rights. The most far-reaching legal change in the Civil War years and after was, of course, with regard to emancipation of the slaves-an issue that had been framed in legal discourse down to 1861, against the rising outrage of abolitionist sentiment, in property-law terms. Without revisiting that dramatic subject, there were interesting cases that arose from wartime policies that touched general property rights in wartime. Two of these cases will be considered, United States v. Pacific Railroad ${ }^{44}$ and Miller v. United States. ${ }^{45}$

Both the arguments of counsel and the opinions of a divided Court in Miller, decided in 1870 , addressed the ways in which the war powers under the Constitution were affected by the terms of the law of nations. That issue was interwoven with others-due process concerns rooted in the Fifth and Sixth amendments, plus the question of whether states in rebellion had a status equivalent to that of foreign enemy states.

By acts of 1861 and 1862, dating from the dark days for the Union cause, when the military outcome of the Civil War was hardly certain, Congress had authorized the President 
to issue a proclamation for confiscation of the property of Confederate civil and military officers (and also all former office-holders in the United States who accepted an office in the Confederate government). The 1862 Act is best remembered, of course, for its historic provisions granting freedom to all slaves who escaped from or were captured by the Union forces in the hands of slave-owners "engaged in [the] rebellion ... or who should in any way give aid and comfort thereto." The statute also authorized the President to employ African Americans "in the suppression of the rebellion," opening the way to their recruitment for the Union armies. ${ }^{46}$

These were revolutionary measures, constituting the portentous first legislative steps toward full emancipation and equal rights for blacks. By contrast, the Union government's implementation of the confiscation policy became largely bogged down by complexities stemming from deference to the northern state governments' policies, conflicting effects of presidential pardons and amnesties, and the like. ${ }^{47}$ Ironically, however, it was a confiscation action, in Miller, that the Court seized upon to re-examine some fundamental constitutional issues that the southern states' secession had raised-and to advance significantly the doctrine of emergency war powers.

Samuel Miller was a locally prominent judge and legislator in Virginia, and he served the Confederate States government and his own state during the rebellion in various public offices, thus clearly qualifying him as a candidate for confiscation action under the 1861 and 1862 statutes. On information ex parte in an affidavit from one Thacher, a New York resident, that Miller had admitted to him in private conversation that he was dedicating 10 percent or more of his income voluntarily to the cause of the Confederacy, the federal district attorney in Detroit moved to attach and confiscate common stock of significant value in two Michigan railroad corporations. ${ }^{48}$ In accord with the procedures specified in the statutes, this was done under admiralty and revenue-collection rules.
In these proceedings, no personal service of notice was required and no opportunity for jury trial was afforded. The federal marshal served notice upon the company offices in Michigan, and then notice of his action was filed in the federal district court by the federal attorney. Following that filing, in early 1864, the government confiscated Miller's stock holdings.

After the war, Miller and then, after his death, his heirs sued in federal court for recovery of his losses by that action. Their claims denied in the courts below, they brought their case to the Supreme Court in the December 1870 term, six years after the confiscation. It was also five years after the Appomattox surrender, but, as the Court's opinions would indicate, important constitutional questions still remained outstanding.

Justice William Strong wrote for the Court, upholding the government, and, in a dissent joined by Justice Nathan Clifford, Justice Stephen Field took issue with virtually every aspect of the majority's decision. On the extent of congressional authority to take enemy property, the majority essentially endorsed the argument of government counsel-that under rules of law in the law of nations, Congress might have ordered confiscation of Miller's property (or any other enemy's) "by the mere force of the statute, without any other proceedings whatever, or it could adopt any other process it should choose." $" 49$

The statutory language had specifically adverted in a preamble to the fact that ordinary judicial process was impossible, by dint of the rebellion's having closed federal courts and offices. Under those circumstances, the character of the emergency bore directly on the validity of suspending ordinary due-process guarantees, opting for revenue and admiralty procedures. Even that aspect of the controversy was not a necessary element of justification in the Court's broad view of governmental power in this emergency context. For once the guns at Fort Sumter had sounded, the condition of war "was alike an actual and a recognized fact, [and] the United States were invested with 
belligerent rights in addition to the sovereign powers previously held." 50

"[T] $]$ he power to declare war," the Court declared, "involves the power to prosecute it by all means and in any manner in which war may be legitimately prosecuted. It therefore includes the right to seize and confiscate all property of an enemy and to dispose of it at the will of the captor." 51 Having thus reconfirmed the broad and virtually plenary authority of Congress vis-à-vis enemies in time of war, the Court also provided a wholesale endorsement of delegation of a wide discretion to the President. The statutes would become effective when the President decided to issue a proclamation initiating their enforcement. Once such a proclamation actually was issued from the White House, however, Congress prescribed specifically that "made it the duty of the President" to confiscate. ${ }^{52}$

Rejecting arguments that the confiscation violated the due-process provisions of the Fifth and Sixth Amendments, the Court further ruled that the statutes, being an exercise of the war power and not criminal law, were not constrained by those amendments. The Court also rejected arguments that the law of nations protected Miller because he was not a foreign enemy. A person abetting a rebellion had no more rights than those of an alien enemy; and the Marshall Court decisions that spoke of rules of war as giving benefit of "civilized" and "humane" consideration to property rights were not taken as mandatory restrictions on the legitimate authority of a government at war.

In a strident and comprehensive dissent, Justice Field contended that the statutes were plainly criminal law, so that the confiscation had been a taking in stark violation of established property rights. By the majority's validation of a proceeding in rem under admiralty and revenue rules against a property holder in this way, Field declared, the court "works a complete revolution in our criminal jurisprudence." ${ }^{53} \mathrm{He}$ was willing to accept the broad scope of the war power as Chief Justice Marshall had laid it out in Brown, but the abridgment of enemy property rights that Marshall had conceded as legitimate should not apply to Miller. "By enemies is meant permanent inhabitants of the enemy's country," Field contended, and Miller's residence in Virginia, even during the rebellion, did not meet that definition. ${ }^{54}$

One final aspect of Miller and its doctrinal heritage is of special interest here, because the majority opinion adverted to a "doctrine of confiscation" in terms that we will encounter again, with broad ramifications, in a case involving seizure of property during World War I. ${ }^{55}$ This element of the Court's findings was derived from its reading of the law of nations. "The whole doctrine of confiscation," expressed in the rules of war in the authoritative texts, "is built upon the foundation that it is an instrument of coercion, which, by depriving the enemy of property within reach of his power ... impairs his ability to resist the confiscating government, while at the same time it furnishes to that government means for carrying on the war." 56

The second Civil War property case of special interest, United States v. Pacific Railroad (1887), came to the Court later in time and involved very large financial stakes. Whereas the Miller confiscation case had involved the dry-as-dust procedural issues of taking intangible property from a company office in a town hundreds of miles distant from the field of battle, the Pacific Railroad case originated with the orders of a Union Army general promulgated in the heat of battle and facing a potentially catastrophic defeat if he failed to act decisively. A Confederate force led by General Sterling Price, in his famous western campaign of fall 1864 , had invaded Missouri and was threatening the defenses of St. Louis, a major Union city. Defending against the Confederate force was General William Rosecrans, who ordered his Union Army to destroy several large, strategic railroad bridges "as a military necessity" in order to slow Price's advance. ${ }^{57}$ St. Louis was spared, and as the tide of battle turned Rosecrans found it equally imperative, 
as a matter of "military necessity," to rebuild those same bridges for use of his own force. He met with the officers of the railroad company, obtaining agreement that they would do as much rebuilding at their own expense as was possible; but the general also announced his intention to order the reconstruction by the government of any bridge the companies lacked the capacity to restore. He would, he said, expect the companies to bear the costs involved for the government in reconstructing bridges, through a withholding of any freight revenues owed them for carrying military or other government freight. If this arrangement were later to come up in a court of law, it was entirely agreeable to Rosecrans; he anticipated a settlement of any dispute "on principles of law and equity." For the moment, however, the vicissitudes of war required instant action, and the railroad's officers were in no position to quarrel with the arrangements that Rosecrans imposed. ${ }^{58}$

Justice Field wrote for a unanimous Court this time, ruling on the company's claim that the government should refund freight earnings withheld since the war on the basis of Rosecrans's order. Unlike in the Michigan bond case involving Miller's property rights, in this instance Field invoked the war powers and government discretion in the broadest terms. The stated "necessities of war" were determinative for the Court, and those "necessities ... called for and justified" both Rosecrans's action in destroying the bridges and his orders for their reconstruction. "The safety of the state in such cases overrides all considerations of private loss," Field wrote: "Salus populi is then, in truth, suprema lex." ${ }^{59}$ In the heat of battle, with invading troops on the march, the Court did not assert the need for close judicial scrutiny of the commanding general's decision to invoke "necessity." As we shall note, some of the landmark twentieth-century cases would be of a different character, both as to wartime situations and as to the shift in emphasis to adjudicating the claims of "necessity" in response to general economic crises in peacetime.
The civil-law doctrine as formulated by Vattel was extensively cited in this opinion, as it had been relied upon repeatedly in the previous deliberations of the Court on emergency power. Approvingly quoted was Vattel's rule that when damage was caused by "inevitable necessity" in the course of active combat, it was no different from loss at the hands of enemy troops. "All the subjects are exposed to such damages; and woe to him on whom they fall! The members of a society may well encounter such risk of property, since they encounter a similar risk of life itself." ${ }^{60}$ Were the state to be held responsible for such private losses in war, moreover, it would completely exhaust the public resources, and hence was "a thing utterly impracticable." 61

Field buttressed his argument further with historical examples that militated against compensation to the company for the bridges rebuilt by the government, citing various decisions by Congress on claims for reimbursement. There was a consistent pattern, he concluded, "[that] sufferings by the general ravages of war had never been compensated by this or any other government." 62 Some emotional effect must have been evoked from another reference-viz., a veto message by President Grant, in which the old commanding general refused to sign a special act of Congress compensating a homeowner for losses suffered when his home, which had served enemy sharpshooters, had been burned on order of Union officers to prevent its being used by the Confederates. Private property, Grant declared, was, "[as] a general principle of both international and municipal law," subject to be occupied, taken, "or even actually destroyed, in times of great public danger, and when the public safety demands," with no legal obligation on the part of the government to pay compensation. ${ }^{63}$

Having endorsed this broad construction of war powers, however, the Court placed on the government, no less than the railroad company, the obligation to carry burdens that war placed upon it. Although there was no 
requirement to pay the company any reimbursement for its expenses in replacing bridges destroyed by the retreating Union forces, the opinion continued, neither was there an obligation upon the company to reimburse the government for the Army's expenses in rebuilding their other bridges. To that extent, the Court did place a judicial barrier in the way of indirect government "impressments," as it were, of private-property rights. And it comes as no surprise that it was Justice Field who wrote for the Court. The decision as he framed it presaged his strong support for both governmental authority (where it met his standard of legitimacy) and famously unyielding arguments for property rights against government action that he believed crossed the boundary line limiting its constitutional authority. $^{64}$

Judicial consideration of where that line ought to be drawn in a wartime emergency was one distinctive kind of exercise in constitutional interpretation. Distinctively different in vital respects was the judicial quest to determine the legitimacy of broad emergency power in economic crises. Especially interesting among the twentieth-century developments were two vital questions. First, could powers once granted in wartime, explicitly to meet the war emergency, continue to be exercised after the hostilities had ended, and if so, was there any limit on their duration? And second-and no less difficult and portentous-was it constitutional (whether a wise policy or not) for Congress to delegate to the Executive broad discretion to declare the existence of emergencies and then suspend normal guarantees of rights? Such authorizations to the President to declare emergencies have proliferated dramatically, in fact, since the $1930 \mathrm{~s}$, both as to scope and as to number of authorizations. To what extent, then, has the "traditional" Constitution-as known until, say, the $1930 \mathrm{~s}$ - been supplanted by a qualitatively different structure of governance, and with effects for the future upon the traditional guarantees of fundamental liberties to which
Earl Warren referred as the underpinnings of "a free government"?

Many historians and legal scholars have written on these themes, and it is not my intention here to go over the same ground very broadly. ${ }^{65}$ Rather, in the concluding section of this study, I want to underline some of the ways in which the constitutional theory of property rights has been of prominent concern to the Supreme Court in its ongoing reconsideration of emergency powers.

* * * * *

The issues we have discussed had typically been embedded, as considered by the high court, in cases arising from the war power. In the twentieth-century cases, one of the Justices' concerns was to clarify the relationship between the powers associated with conduct of war and the "ordinary" emergency power as exercised by civilian government in peacetime. I want to examine here some specific doctrines that the Court formulated in this enterprise, but also to discuss briefly the larger process of changes in policy and law that have produced the seemingly irreversible increase in the Executive's power and the consequent distribution of real power in the modern American constitutional order.

\section{The Impact of Mobilization During World War I}

When the United States entered World War I, the President and Congress moved quickly to put policies in place for mobilization of labor and resources. In addition to sweeping laws regulating freedom of speech and instituting censorship of the press through controls over use of the mails, Congress authorized the President to nationalize or take over the operations of railroads and water-transport systems, telephone and telegraph companies, and ship-building facilities. Under the Lever Act of August 1917, further presidential powers were legislated, covering a vast array of economic 
activities and interests. Given unlimited authority to create agencies and reorganize the government to implement Lever Act powers, President Wilson ordered new controls over mining, food supply and prices, mineral production, and the processing of alcoholic beverages. Meanwhile, Congress extended virtually plenary power over the property of enemy governments and enemy aliens, together with authority to establish comprehensive presidential control over imports and exports. ${ }^{66}$ All this, of course, happened parallel to the harsh campaign of repression of speech and press under espionage and sedition acts, against the background of a war-propaganda operation under the Committee for Public Information, that further enhanced Executive authority and curtailed traditional individual rights in addition to the property rights affected by the economic controls. $^{67}$

Two constitutional issues that arose from the administration of emergency powers during the war and the immediate postwar years are of special interest to us in light of the earlier history. The first issue-a familiar one, with roots in the Marshall Court decisionsconcerned the property rights of enemy aliens as presented in the case of U.S. v. Chemical Foundation, Inc., decided in October 1926, eight years after the armistice that ended hostilities. ${ }^{68}$ It is a curious case in that the petitioner was the federal government itself, which had brought suit to obtain invalidation of a transfer of certain industrial patents "seized" as enemy property during the war. The wartime government officer in charge, the Alien Property Custodian, had taken control of valuable patents to chemical processes, together with various trademarks, and then transferred this property by sale. The purchaser was the Chemical Foundation, a corporation founded under the laws of Delaware in 1919 for the stated purpose of purchasing the patents in question. Once it had ownership, the foundation was empowered to manage these rights "in a fiduciary capacity for the Americanization of such industries as may be affected thereby, for the exclusion or elimination of alien interests hostile or detrimental to the saidindustries, and for the advancement of chemical and allied science and industry in the United States. ${ }^{\prime 69}$ The transfer of the patent rights was made at private sale for $\$ 271,000$. It was done without notice, an unusual arrangement justified by a provision obligating the corporation "to grant non-exclusive licenses upon equal terms to qualified American manufacturers., 70

The corporation apparently was up and running, and bringing in revenues that supported the salaries of its top officers and directors, meanwhile contributing to the "Americanization" of technologies that had been developed in Germany and the stream of revenue that they were producing. All this attracted the government's attention when Warren Harding's appointees in the Justice Department succeeded the Wilson administration after the 1920 election. What the government's lawyers found improper - and possibly illegal - was that the same individuals as had conceived the project of forming this corporation and had provided the legal counsel on which the terms of the patent transfer to the corporation had been written were also the key officers and directors of the corporation. They included, above all, the Alien Property Custodian himself!

The government initially filed a complaint in federal district court, alleging: that a small group of chemical manufacturers had conspired to obtain these patents "at nominal prices" through the establishment of the Chemical Foundation, Inc.; that they had used the patents obtained to further combinations and monopoly of "certain chemical industries" in the United States; and that the property had been obtained through "fraudulent deception" in violation of federal statutes governing the terms of sale for government property. The trial court rejected the claim of unlawfulness in the transfer, and the case came to the Supreme Court on appeal on the question of whether the sale had been illegal under the statutes forbidding conflicts of interest such as appeared 
so blatantly here when government officers or fiduciaries transferred property held by the federal government.

In accord with the basic doctrine of the law of nations, adopted by the Marshall Court in the early cases and asserted in categorical terms again in Civil War cases, ${ }^{71}$ the Court now reaffirmed that enemy property is entirely at the mercy of the U.S. government when the war powers are invoked legitimately. As a war measure, the Trading with the Enemy Act "should be liberally construed," the Court declared. The power of a war government was plenary: "Congress was untrammeled and free to authorize the seizure, use or appropriation of [enemy] properties without any compensation to the owners." Although the government might stand ready to negotiate compensation with Germany or its nationals, this matter was not a justiciable one. The President had been free to determine at his discretion how the properties should be disposed of, by what agency, and under what terms. Hence, the contract for transfer stood valid and binding.

This sweeping reaffirmation of plenary government control over enemy alien rights would take on even greater importance in a later era of American constitutional law, when the Court effectively merged the Chemical Foundation ruling on unlimited presidential authority in this regard (under the Trading with the Enemy Act, still in effect, amended, well into our own day) with the doctrine of exceptional breadth of presidential authority vis-àvis Congress in foreign affairs, set forth in the famous Curtiss-Wright decision of the late $1930 \mathrm{~s}^{72}$

The second issue of long-term importance to which I would like to give brief attention is the "durational" one with respect to war measures. This had come up to the Court in various Civil War era cases, ${ }^{73}$ but after November 1917 the question arose again, with respect

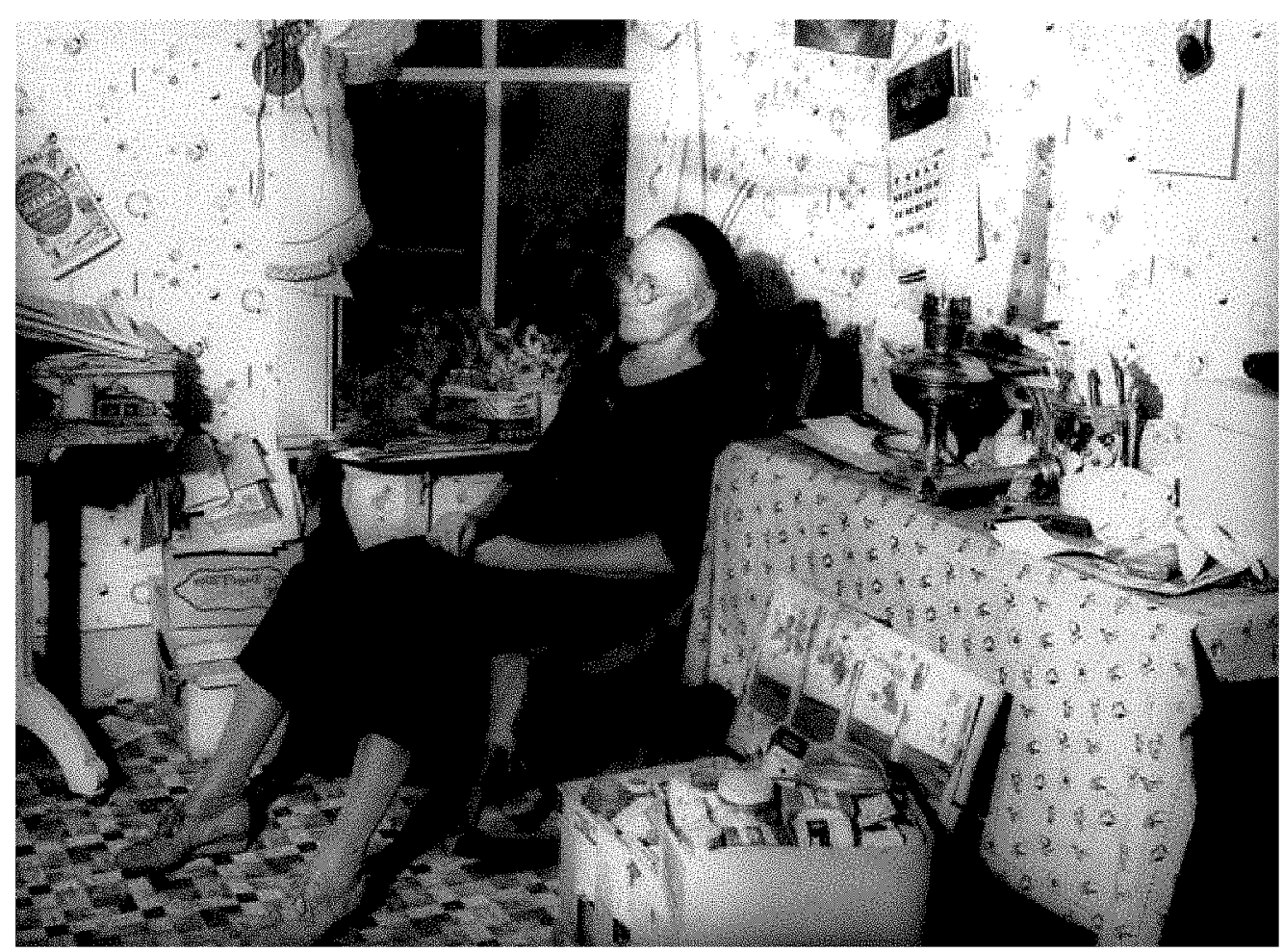

This widow from a small Texas town wrote to President Roosevelt in 1942 pleading for rent control so that she and her daughter would not be evicted from her home. The Office of Emergency Management imposed rent controls during the war to protect those living on the home front. 
to legislation actually enacted after the cessation of hostilities but before any formal end to the war by treaty. The cases raising this issue concerned the prohibition of manufacture and sale of hard liquor, and also the imposition of rent controls in the District of Columbia. The Court ruled that such emergency legislation was valid under the war powers not only during the period of the fighting, but for a reasonable period beyond that time.

In two decisions written by Justice Oliver Wendell Holmes, Jr., the arguments of "necessity" for the rent-control legislation were considered in a framework of analysis that was embedded in police-power jurisprudence. That is to say, Holmes argued that, like traditional peacetime powers for regulation of public health, safety, and welfare, the war powers might go "to the verge" and so be found to require payment of compensation to property owners who suffered from government action. But as late as 1921, in his opinion for the court in Block v. Hirsh, ${ }^{74}$ he ruled against the contention that there had been an effective "taking" in the rent controls. Three years later, however, the Court looked again at the question of whether changed circumstances had rendered the same law unconstitutional. ${ }^{75}$

The Court's reaffirmation that the termination of hostilities was not determinative as to emergency powers was only one side of the coin. The other was that by stressing the importance of "circumstances," the Court was, in effect, asserting here that it would examine the factual evidence presented in suits relating to the continued existence of emergency conditions. It would not take a congressional statement regarding the "necessity" issue as determinative. We will encounter this important question-viz., who has the final say as to necessity, whether of a congressional emergency statute or an act of a military commander in the field or at sea? - in other decisions that followed.

One final observation is appropriate concerning the impact of constitutional change during World War I. Because the Trading with the Enemy Act remained in force, with its provisions for presidential declaration of a war-related emergency, a significant arsenal of latent authority was available to Franklin D. Roosevelt when global events during the 1930s presaged the outbreak of World War II. In the interim, since the Hundred Days of 1933, Congress had given the President a great panoply of new emergency powers with which to address the economic crisis in the Depression. "Even before 1939," Clinton Rossiter has written, "Mr. Roosevelt, in an emergency to be ascertained and declared by himself, could have prohibited transactions in foreign exchange, seized power houses and dams, increased the army and navy beyond their authorized enlisted strength, devaluated the dollar, forbidden all Federal Reserve transactions except under regulations which he approved, seized (in war or when war was imminent) any plant refusing to give preference to governmental contracts or to manufacture arms for a fair price, requisitioned any American vessel, and exercised complete control over all communications in the United States."76 Openended congressional authorizations empowering the Executive to declare an emergency had effected that fundamental change in the constitutional order that has been so frequently remarked.

Even in the first years of his administration, when emergency power centered only on the domestic economic crisis, FDR so often invoked the Trading with the Enemy Act and the arsenal of earlier constitutional adjudications on the emergency power that it could plausibly be said that Roosevelt was governing largely on the basis of "the First World War Constitution"! ${ }^{77}$ By the end of World War II, however, that version of the Constitution had yielded to one even more dramatically subject to presidential powers under invocations of emergency. The number of statutes authorizing the President to suspend normal processes and constitutional guarantees, along with the scope of their subject matter, continued to expand through the decades following the war. And, of 
course, with the current crisis following 9/11, the constitutional issues involved today are of new and urgent importance.

\section{The New Deal and After: A Transformed Constitutional Order}

Reflecting on the events of his first hectic months as President in 1933, the year of the Hundred Days and the founding of the New Deal, FDR wrote: "Every day that went by ... brought before me and the Cabinet and the Congress some new emergency which cried out for action." 78 The responses that Roosevelt espoused, insofar as they were not merely pragmatic and asserted ex cathedra, rested upon the constitutional foundation of emergency powers. It is axiomatic in the work of virtually all constitutional historians and analysts of 1930 s political history to begin with the words from FDR's inaugural in which he compares the Depression to a war-and tells the country, and Congress in particular, that he requires the same degree of discretionary power as though it were an armed conflict. Throughout the New Deal years, the rhetoric of "war" persisted, as it does in a different context today (the "war on terror," the "war on drugs," and other causes and policies). And Roosevelt never let up in pressing the Congress for expanded statutory authority, never failed to interpret in the broadest possible terms such authority as was given him in legislation. Not least important, he never slackened in pressing claims to act on prerogative power by asserting the inherent authority of the President as "commander-in-chief" or in exercising general "executive" powers.

The high point of drama in that constitutional story, more than matching the significance of even the "Court-packing" episode, was an overt threat from FDR in 1942 (during one of the most difficult periods of the war) to nullify a statute if Congress did not do his will. This was in relation to a provision of the Emergency Price Control Act that exempted agriculture from the wartime controls to a degree that Roosevelt believed was un- dermining the economic regime and harming the war effort. "In the event that the Congress should fail to act, and act adequately," he proclaimed, "I shall accept the responsibility, and I will act." $"$ In that instance, Congress yielded, and the issue was quieted. In many other instances, however, both as to economic measures and as to foreign policy, taking broad liberties with both the Constitution and the specific terms of neutrality legislation, Roosevelt did not bother to go to Congress at all, whether to seek compliance after the fact or to make explicit threats. Domestic emergency and overseas threats spoke for themselves as justification for executive initiatives in the implicit philosophy of his administration. ${ }^{80}$

The full story of the New Deal and the Court - and especially the "constitutional revolution" that so fundamentally altered the inherited "Lochner era" and interwar doctrines of contract, police-power, and separation-ofpowers law - has been told many times (albeit in divergent interpretive versions) by eminent scholars, and there is little purpose in reviewing that aspect of the property-rights issue here. ${ }^{81}$ In addition, however, to the Court's responses to those questions, largely raised by congressional legislation and actions of the Executive, there was another dimension of judicial response to which I do want to give brief notice. This was the way in which the Justices sought to work out what might be termed a "generic" emergency-power doctrine that would be applicable generally, at least in peacetime, and that could be a reliable and consistent check against abuse of property rights. The Court's approach to this problem was exemplified in the famous Minnesota Mortgage case, to which we turn next.

\section{The "Generic" Emergency Power: The Rhetoric of Rights, Powers, and "Necessity"}

In few areas of constitutional law has the Supreme Court produced such ambiguous rhetoric, so many Delphic pronouncements, and such complex doctrinal confusion as it 
long did in its quest for a generic doctrine of emergency powers. In the war-powers cases, the lines had been drawn fairly clearly-and resolved largely in the government's favor, as has been noted here. In the matter of peacetime uses of emergency powers, however, as the Great Depression spread its baleful effects throughout the nation, the Court's position was anything but certain.

The case of Loan Association v. Blaisdell $^{82}$ brought to the Court a challenge to the constitutionality of a mortgage-payments moratorium law enacted in Minnesota in 1933. The statute was enacted amidst a wave of foreclosures that was feeding what the Minnesota attorney general declared in argument was a perilous decline of public order. Declaring an emergency, the statute provided for "temporary and conditional relief" 83 by authorizing state trial courts to stop a foreclosure and approve extension of time for payments due. Significantly, the act was to be effective "only during the continuance of the emergency" and in any event for no longer than two years from the time of its passage. ${ }^{84}$

Argument centered on whether the extension of state police power to this extent was in blatant violation of the Contract Clause, which, after all, had been written in the1780s against the background of "stay laws" not much different than Minnesota's statute. Was the emergency of such moment that it warranted an abrogation —even if only temporary —of obligations of a mortgage contract? And if so, on what principle would a limit on the reach of the Contract Clause owing to emergency conditions be justified in generic terms?

The Court had already faced such a question two years earlier in a more familiar type of police-power case, New State Ice Company v. Liebmann. ${ }^{85}$ The regulation of ice business by the State of Oklahoma was at issue, and the Court's majority, including Chief Justice Charles Evans Hughes, struck down the law on grounds that the ice business was not "affected with a public interest"- the standard, dating from Munn in 1877, that was still being ap- plied regularly when state regulatory laws were challenged. Justice Louis Brandeis's dissent in this case is famous for its memorable argument that the principles of constitutional federalism meant that "a single courageous State may, if its citizens choose, serve as a laboratory; and try novel social and economic experiments without risk to the rest of the country." What is recalled less commonly is that Brandeis did not rely wholly on the appeal to the principle of federalism: he also contended for recognition by the Court of exceptional circumstances. The Depression, he asserted, in language that foreshadowed FDR's famous declaration in his 1933 inaugural speech, had produced "an emergency more serious than war." For the Court to apply the tired standard of business affected with a public interest, discounting completely the urgency of such a crisis, appeared to Brandeis a dangerous course. ${ }^{86}$

By introducing the emergency aspect through a focus on circumstances in the Oklahoma case, Brandeis was invoking a standard of adjudication in regard to property rights that resonated with the reasoning applied in at least one major case of an earlier day involving state (as opposed to national) authority. Specifically, in Noble State Bank v. Haskell in 1911, the Court, in a unanimous opinion written by Justice Holmes, had upheld an Oklahoma statute that required banks to pay compulsory assessments to support a statewide deposit guarantee fund. Although it was a less startling use of the regulatory power than the Minnesota mortgage moratorium twenty-three years later, still it was open to a serious challenge under the terms of the Contract Clause. The Court's decision upholding the Oklahoma statute was rendered at a moment when the Panic of 1907 , a serious event in the national financial markets, was still a fresh memory. It was therefore especially significant in the history of property rights and emergency powers that Holmes specifically stated that the Oklahoma law had been enacted in hopes that it "would make a [bank] failure unlikely and a general panic almost impossible." The power 
of a state to head off an emergency in this way "must be recognized, if government is to do its proper work." 87

In judging the constitutionality of such statutes, Holmes went on to say, it was of course necessary to draw lines as to their reach and constitutional limits: "[As] elsewhere in the law," he wrote, "lines are pricked out by the gradual approach and contact of decisions on the opposing sides." 88 Here, then, was precisely the same approach as that which Holmes would apply in the post-World War I rentcontrol cases. The Court would consider circumstances, and after making a determination as to whether the state government's action was reasonable in light of those circumstances, it would decide whether the cumulative "pricking out" process had come so far that the dots had been connected and a firm doctrinal boundary line had been formed. ${ }^{89}$

The echo of those cases and principles of adjudication were heard in the Hughes Court's approach to the issues posed in Blaisdell. Writing for the majority, the Chief Justice underlined the urgency of conditions in Minnesota that lay behind the legislature's decision to adopt such a measure, quoting from Marshall in McCulloch v. Maryland the famous phrase that "[I]t is a Constitution we are expounding ... intended to endure for ages to come and consequently to be adapted to the various crises of human affairs. ${ }^{.90}$ Adverting to the evidences of far-reaching social instability and the threat of violence that Minnesota had introduced in argument, Hughes compared the economic crisis there to the "limited and temporary interpositions" that the Constitution must permit, even against the Contract Clause's terms, "if made necessary by a great public calamity such as fire, flood, or earthquake." To ignore the severity of the crisis in Minnesota, would amount to a blindness to the importance of "the maintenance of a government by virtue of which contractual relations are worth while." Having made this important rhetorical move, Hughes then proceeded to attempt a generic construct that would serve as a principled basis for application of emergency powers-a construct that would be responsive to what he termed the "growing appreciation of public needs and of the necessity of finding ground for a rational compromise between individual rights and public welfare." 91

At hand for Hughes in Blaisdell was the highly enigmatic dictum, from a 1917 decision, that "[A]lthough an emergency may not call into life a power which has never lived, nevertheless emergency may afford a reason for the exertion of a living power already enjoyed. $" 92$ This effort at a generic doctrine was suggestive but hardly sufficient, as Hughes recognized, and so he offered his own formulation of the appropriate general principle: The existence of an emergency itself, Hughes wrote, "does not create power;" however, "emergency may furnish the occasion for the exercise of power.... The constitutional question presented in the light of an emergency is whether the power possessed embraces the particular exercise of it in response to particular conditions." 93

Not long after deciding Blaisdell, the Court shifted ground in its decisions on comparable regulatory measures in the states that were prompted by Depression conditions. Rather than adhere to the approach it had taken in the Minnesota case, building on the concept of emergency power, the Court instead allowed a much broader discretion for state legislatures in their decisions and programs for economic regulation by two famous shifts away from earlier doctrine: by its repudiation in Nebbia v. New York" of the "affection with a public interest" standard for judging which specific economic interests might be regulated and which ones must be immune; and by its extension of the congressional regulatory power's reach under an expansive interpretation of the Commerce Clause. The latter movement, essentially giving Congress a broad-ranging police power in economic regulation, culminated in Wickard v. Filburn. ${ }^{95}$

Historians and legal scholars have recognized the importance of Filburn as a landmark 
Commerce Clause case. What is almost never mentioned, however, is the important fact the Court decided this case in the parlous early days of America's involvement in combat during World War II. It was in the midst of emergency conditions, then, with a full mobilization of the economy and of labor under way, that the Court upheld in Filburn an extreme degree of governmental control over the cultivation and uses of farm products. Whether the Court would have reached so firm a position on what now amounted to a nearly plenary police power for Congress had the case come up in a different context unrelated to war emergency is a question worth pondering. In any event, the kind of efforts that the Court had made earlier toward constructing a generic emergency power doctrine - most notably in Wilson v. New and in Blaisdell - had proven to be a false start. It had given way to action along these other doctrinal paths that the Court followed in its progressive accommodation of the new impulse for enlarged governmental authority over property rights and operations of the economy generally. ${ }^{96}$

And so the Court has made a record of giving ground in both the New Deal and the World War II periods with respect to state regulatory regimes, and from that time to the present day with respect to war powers, as Congress itself has vested the President with a wide and powerful discretion with respect to invoking emergency powers in the name of national security. It would be misleading, however, to conclude that the Court had removed itself altogether from any role in protecting property rights when emergency powers were at issue. This was signaled by the extraordinary Steel Seizure case, Youngstown Sheet \& Tube Company v. Sawyer, decided by the Court in $1952 .^{97}$

\section{Executive Powers and Judicial Intervention: The Steel Seizure Case}

The Steel Seizure case was concerned above all with adjudging the claims advanced by the Truman administration as to the "inher- ent powers" of the President. American troops were in the field of battle in Korea, and a steel strike was in the offing that would undercut production in this vital war-related industry. Hence, President Truman ordered the Secretary of Commerce to seize the nation's steel plants and operate them under government direction until the strike issues had been settled. In his opinion for the Court's six-member majority, Justice Hugo Black ruled that the principle of separation of powers must prevail, and since no congressional statute had authorized the President to seize these industrial facilities, his action was patently unconstitutional.

One centrally important aspect of the Steel Seizure case merits brief additional mention here. ${ }^{98}$ Government counsel pressed the Court to be mindful of what it termed "the necessity, the vital necessity" of keeping the steel mills running. Their argument from this premise, of course, was that responsibility properly rested with the President, and not the judiciary, in establishing whether such "vital necessity" should prevail over other considerations, even what in less urgent situations might be legitimate constitutional barriers. ${ }^{99}$ Here was the time-honored claim, then, of "necessity"-and the persistent question whether, once the Executive (or, in a different context, the military authorities under authority of the President as Commander-in-Chief) declares an emergency, administrative discretion prevails and is immune from effective judicial review of circumstances as well as the law.

President Truman and members of his administration had said in widely noticed public statements that the question lay outside the proper realm of the judiciary. The same argument denying jurisdiction was made by the government lawyers in the lower courts. To Justice Black, we can be certain, this was a challenge of a very special order. For one so dedicated to the notion of the federal courts as the palladium of liberty, one must think, no argument would have been more unacceptable than a claim that the Supreme Court should rule itself out of the arena of constitutional 
process. This had been Black's stated position earlier in the 1946 martial law case Duncan v. Kahanamoku, when he wrote the Court's majority opinion ruling that the Army's military administration in Hawaii during World War II had been illegal. Perhaps even more tellingly, Black had expressed the same concern in even stronger terms in his private exchanges with the other Justices, including especially Chief Justice Harlan Fiske Stone, when the latter sought to soften and narrow draft opinions that Black circulated while Duncan was being considered. His message was simple: if the Army and the government can close federal courts in Hawaii and keep them from functioning to protect due process and constitutional liberty, then by the same reasoning, they could close the Supreme Court itself. ${ }^{100}$ The Court thus made clear in Duncan that it would not supinely accept as determinative a decision by the military that "necessity" required a prolonged imposition of martial law in the absence of invasion or insurrection when there was no statute law or constitutional provision on which such a policy could be justified.

That the Court has an important role to play in scrutinizing claims of "necessity" when emergency powers are invoked is a proposition given special force, moreover, by what historical study in archival records has proven with respect to the way in which the notorious Japanese-American internment cases were argued during World War II. We know now that the Solicitor General, in oral argument before the Supreme Court, suppressed evidence that clearly would have discredited the Army's claims that there was imminent danger of sabotage or espionage and that time pressure had required the mass removal of Japanese Americans from the West Coast without conducting loyalty investigations of individuals that would have indicated the degree of any real danger that was posed by their presence. ${ }^{101}$

In Youngstown, though by no means denying congressional authority to vest specific emergency powers in the Executive, the Court asserted its power to hold the President ac- countable when the terms of statutory grants of power were exceeded, let alone when Congress had authorized a different way of handling the emergency. ${ }^{102}$ When the Court's decision was announced, Earl Warren, then governor of California, welcomed it because of its reaffirmation that "[E]veryone in the nation, including the President, is subject to the written provisions of law." 103 And, as Maeva Marcus's analysis of the Court's later decisions on separation of powers and on claims of inherent presidential powers has shown, the Youngstown Court's basic proposition regarding rule of law under the Constitution was deployed successfully against the Nixon administration to confront a President bent on asserting uncontrollable power in defiance of the judiciary and Congress alike. ${ }^{104}$ The persistence of this ruleof-law ideal has operated prominently, too, in the post-9/11 "war on terror," as lower federal courts and units within the Department of Justice itself have engaged in an ongoing, intensive confrontation between "necessity" and the nation's traditional commitments to liberty and constitutional due process. ${ }^{105}$

The division of opinion among the Justices in Youngstown was an indicator of the Court's continuing inability to formulate a workable generic theory of emergency power. Indeed, Jackson adverted to "the poverty of really useful and unambiguous authority applicable to concrete problems of executive power as they actually present themselves .... A century and a half of partisan debate and scholarly speculation yields no net result but only supplies more or less apt quotations from respected sources on each side of any question. They largely cancel each other." The Delphic pronouncements of the Court in Blaisdell and other earlier cases did not serve. Hence, Jackson offered an alternative approach to assessing constitutionality of presidential actions according to a categorization of "practical situations" based on cases "as they actually present themselves."106

Jackson's effort at working through the conceptual problem was reminiscent of Chief 
Justice Stone's dictum in his concurring opinion in the Hawaii martial law case. Stone wrote that the meaning and reach of "martial law" must be viewed in terms of the situation presented to the Court: "Its object, the preservation of the public safety and good order, defines its scope." But even this pragmatic approach could not be open-ended. "A law of necessity," Stone declared, can justify important sacrifices of constitutional liberty in order to avoid undermining national defense and security when military power needs to be exercised in a war emergency. Stone ended by going full circle, however, stating that government's power to command such sacrifice "may not extend beyond what is required by the exigency which calls it forth." 107 Thus, in the Hawaii case, he would not accept as fiat the military commander's judgment of necessity, and after reviewing the situation that had produced the decision to impose martial law and assessing the persuasiveness of the evidence that had been presented at trial as to imminence of real danger, Stone found against the Army.

\section{The Pacific Railroad Doctrine Revividus: Caltex of the Philippines}

One encounters no comparable ambiguities or judicial angst over the application of traditional emergency-powers doctrines when the Court considered the conventional issue of property losses in the heat of battle. In U.S. v. Caltex of the Philippines, Inc. ${ }^{108}$ a case decided in 1952, the issue was similar to that of the Civil War situation in which bridges were burned in order to defend St. Louis against Price's army. In Caltex, a private corporation that owned large facilities of storage and movement of fuel oil in the Philippines suffered heavy financial losses when the commander of U.S. forces in Manila seized the properties as Japanese invading forces were advancing toward the port and Japanese bombers were attacking the city. To have the Caltex facilities and fuel taken by the Japanese and used for their naval vessels would have been catastrophic from the standpoint of American forces in the Pacific. The American military torched the facilities as Japanese troops were literally entering Manila. After the war, Caltex sued for compensation.

In an 8-1 decision, the Court cited the doctrine of "necessity" in precisely the terms that Justice Field had done in Pacific Railroad, stating that losses experienced in this manner in the heat of battle fell upon the unfortunate sufferers. Field was quoted at length on this point:

The destruction or injury of private property in battle, or in the bombardment of cities and towns, and in many other ways in the war, had to be borne by the sufferers alone as one of its consequences. Whatever would embarrass or impede the advance of the enemy, as the breaking up of roads, or the burning of bridges, or would cripple and defeat him, as destroying his means of subsistence, were lawfully ordered by the commanding general. Indeed, it was his imperative duty to direct their destruction. The necessities of the war called for and justified this. The safety of the state in such cases overrides all considerations of private loss. ${ }^{109}$

Whether or not what Field had written was only "a maxim" at the time, the Caltex Court declared, "It is law today." 110 Hence, the corporation could not hope, in this case, to receive compensation for its loss. Had the same losses occurred in the heat of battle as the Japanese directly engaged U.S. forces, as happened immediately after the torching, certainly no claim for compensation would have been honored. Therefore, the Army's decision to destroy the property when enemy forces were actually in sight, with Japanese capture of the port nearly certain, had to be judged in the same light. It was not a "taking" or impressment of property, requiring compensation, for the U.S. military 
commanders were not seeking to appropriate the facilities and fuel for their own use in field operations. ${ }^{111}$ The torching of the property had been intended to prevent the enemy from having the advantage of using it against the United States and its Pacific forces. ${ }^{112}$ And so the "fortunes of war" argument- the extreme version of "necessity" and salus populi from the common law-prevailed here, just as it had done in classic emergency situations since the beginnings of the Republic. Here there was no difficulty deriving from lack of an adequate generic theory.

\section{Conclusion}

The Caltex story can serve as a reminder of the historic core doctrine from which emergency powers took root-and of the durability of that legacy. However, the larger history of the Supreme Court's efforts to tame and cabin the reach of powers justified by "necessity" and to fashion a proper balance between emergency imperatives and the guarantees of constitutional liberty, including the protection of property rights in various forms - the history that I have sought to illustrate with the cases discussed here-is indicative of how complex and challenging is the vital process of constitutional adjudication in a system that rests upon the fundamental ideal of a free government "on trial for its life."

*Acknowledgments: This study is based in part on a lecture delivered at the U.S. Supreme Court in fall 2002 under auspices of the Supreme Court Historical Society. I wish to thank Justice John Paul Stevens for his hospitality and his generous introduction on that occasion, and to thank Justice David H. Souter for his interest in the project. I am grateful also to Rob Tennyson and Kathryn Mengerink of the University of California, Berkeley for excellent bibliographic and research assistance. My wife, Jane L. Scheiber, is coauthor with me of published articles and a book in progress on martial law in World War II Hawaii, and in that capacity, as well as from our several collaborations in research on the history of civil liberties, she has contributed importantly to whatever may be of merit in the present work. Any errors of fact or interpretation are my own alone.

\section{ENDNOTES}

${ }^{1}$ Earl Warren, "The Bill of Rights and the Military," in The Great Rights, ed. Edmond Cahn (New York, 1963), 89 (lecture delivered in 1962).

${ }^{2}$ See, inter alia, Clinton L. Rossiter, Constitutional Dictatorship: Crisis Government in the Modern Democracies ([original edition], Princeton, 1948), a book that remains a uniquely insightful analysis of emergency powers, its enduring importance being reflected in the influence it has had in framing the conceptual basis for most recent studies on this theme. See especially ibid., chapter 18 , on the World War II period. The full reach and impact of martial law were experienced in the Territory of Hawaii during World War II, in an episode of martial law and military government that is unique in American history for its duration and the number of citizens affected, on which see Harry N. Scheiber and Jane L. Scheiber, "Bayonets in Paradise: A Half-Century Retrospect on Martial Law in Hawai'i, 1941-46," Hawaï Law Review, 19 (1997), 477648.

${ }^{3}$ Woods v. Miller, 333 U.S. 138, 146 (1948) (Jackson, J., concurring); Korematsu v. United States, 323 U.S. 214, 246 (Jackson, J., dissenting).

${ }^{4}$ Jules Lobel, "Emergency Power and the Decline of Liberalism," Yale Law Journal, 98 (1989) 1385; Harold H. Koh, "Why the President (Almost) Always Wins in Foreign Affairs: Lessons of the Iran-Contra Affair," Yale Law Journal, 97 (1988) 1255; Gordon Silverstein, Imbalance of Powers: Constitutional Interpretation and the Making of American Foreign Policy (New York, 1997). The expansion of presidential discretionary authority during the Cold War years also was built upon a key shift in constitutional doctrine in the New Deal era, expanding Commerce and Contract Clause doctrine as an alternative to a more confining emergency powers doctrine, as Michael R. Belknap has shown in "The New Deal and the Emergency Powers Doctrine," Texas Law Review, 62 (1983) 67f., and as is explored further (stressing the cultural change reflected in legal realism, acceptance of deference of legislative judgments, and the Court's famous downgrading of property rights as less than a "preferred freedom") in Daniel Hulsebosch, "The New Deal Court: Emergence of a New Reason," Columbia Law Review, 90 (1990), 1973

${ }^{5}$ See, e.g., Mark E. Neely, Jr., The Fate of Liberty: Abraham Lincoln and Civil Liberties (New York, 1991); Harry N. Scheiber, The Wilson Administration and 
Civil Liberties, 1917-1921 (Ithaca, NY, 1960); Gilbert C. Fite and H. C. Peterson, Opponents of War (Madison, WI, 1957); Peter Irons, Justice at War: The Story of the Japanese-American Internment Cases (New York, 1983); Melvin I. Urofsky, Division and Discord: The Supreme Court Under Stone and Vinson, 1941-1953 (Columbia, SC, 1997).

Rossiter, Constitutional Dictatorship, remains, as noted above, of unique importance. The constitutional issues as framed by Rossiter and others have been revisited in a wide-ranging fashion in a recent article by Oren Gross, "Chaos and Rules: Should Responses to Violent Crises Always Be Constitutional?" Yale Law Journal, 112 (2003), $1011 \mathrm{ff}$. For a valuable study from a present-day comparative perspective, see Venelin I. Ganev, "Emergency Powers and the New East European Constitutions," American Journal of Comparative Law, 45 (1997), 585ff. See also Jon B. Gould, "Playing with Fire: The Civil Liberties Implications of September $11^{\text {th }}$," Public Administration Review, 62 (2002), 74-79.

${ }^{6}$ See Roger Daniels, Sandra C. Taylor, Harry H. L. Kitano, and Leonard J. Arrington, eds., Japanese Americans: From Relocation to Redress (Seattle, 1986); and Irons, Justice at War.

${ }^{7}$ A copy of this questionnaire is in the files of the civil case of Zimmerman v. Poindexter et al., Case \#730 (1950), Civil Case Files, Records of the U.S. District Court, District of Hawaii, Record Group 21, Sierra Pacific Regional Records Center, San Bruno, California.

${ }^{8}$ Dillon S. Myer, Uprooted Americans: The Japanese Americans and the War Relocation Authority (Tucson, AZ, 1971), 255. Myer states here that the War Relocation Authority staff estimated that some U.S.\$200 million worth of property was owned by evacuees who were interned; the government paid $\$ 38,474,140$ after the war, a sum which, he writes, "of course did not cover all losses." In addition, the State of California moved aggressively during evacuees' incarceration years to bring escheatment actions against properties found to have been owned by alien Japanese residents. There is no estimate given of losses suffered in those proceedings. Ibid., 254-55.

${ }^{9}$ And this says nothing of the ways in which the heated rhetoric with which governments often justify emergency powers in a war atmosphere can inflame public opinion and set the stage for instances of private violence, not only against property, but (as with lynchings and the mob violence against labor organizations during World War I) against life itself. See Fite and Peterson, Opponents of War, passim.

${ }^{10}$ See David M. Kennedy, Freedom from Fear: The American People in Depression and War, 1929-1945 (New York, 1999), 641-42 et passim on this incident and the larger context of wartime labor and other economic controls.
${ }^{11}$ Caltex v. United States, 120 Court of Claims 518, 554 (Jones, C. J., dissenting). The case went on appeal from this court to the Supreme Court and is discussed in the text below.

${ }^{12}$ See Harry N. Scheiber, "Public Rights and the Rule of Law in American Legal History," California Law Review, 72 (1984), 217 ff.; id., "Economic Liberty and the Constitution" [The Seaver Institute Lecture at the Huntington Library], in Essays in the History of Liberty (San Merino, CA, 1988), 75ff.; and id., "Private Rights and Public Power: American Law, Capitalism and the Republican Polity," Yale Law Journal, 107 (1997), 823-61.

${ }^{13}$ Harry N. Scheiber, "The Jurisprudence-and Mythology—of Eminent Domain in American Legal History," in Liberty, Property, and Government: Constitutional Interpretation before the New Deal, ed. E. F. Paul and H. Dickman (Albany, NY, 1989), 217, 223-25.

${ }^{14}$ William J. Novak, The People's Welfare: Law and Regulation in Nineteenth-Century America (Chapel Hill, NC, 1996), passim.

${ }^{15}$ See James B. Thayer, "The Right of Eminent Domain," 19 Monthly Law Reporter (n.s., 1856), 241-42 et passim on the heritage of the common-law cases from England and from the civil-law writers, upholding the "attributes of sovereignty ... coeval with the State itself" being as much a "natural right" of the State as any individual rights were "natural." $C f$. George Haskins, "Law versus Politics in the Early Years of the Marshall Court," University of Pennsylvania Law Review, 130 (1981); and Novak, People's Welfare, passim.

${ }^{16} \mathrm{~A}$ tort case from the early seventeenth century known to every law student in torts class, Mouse's Case (77 Engl. Rep. 1341), decided claims against a bargeman in England who ran into a storm while carrying passengers and their baggage. He had overloaded the barge, and when it was threatened with capsizing, he threw the baggage overboard in order to protect the vessel and save the passengers in his charge. When the English court decided the case, he was found exempt from liability because he had acted in the interest of the passengers; the court specifically invoked the controlling importance of the public good in this private law context. The doctrine of immunity from damages set forth in that case reinforced the doctrines in the common law that protected public officials from individual civil liability for damages when they acted in emergencies to head off disastrous losses of life or property or to protect the public health from spread of disease.

${ }^{17}$ Novak, The People's Welfare, passim.

${ }^{18}$ Beekman v. Saratoga and Schenectady Railroad, 3 Paige 45 (N.Y. Ch. 1831) at 73 (Walworth, Ch.).

${ }^{19}$ Tony A. Freyer, "Reassessing the Impact of Eminent Domain in Early American Economic Development," Wisconsin Law Review 1981 (1981), 1263-86; Harry N. 
Scheiber, "Property Law, Expropriation, and Resource A1location by Government, 1789-1910," Journal of Economic History, 33 (1973), 232-51; id., "The Road to Munn: Eminent Domain and the Concept of Public Purpose in the State Courts," Law in American History, ed. Donald Fleming and Bernard Bailyn (Boston, 1971), 329402. diss.

${ }^{20}$ Eminent-domain takings did, of course, require compensation under the terms of the Fifth Amendment and the provisions of nearly all state constitutions. But in practice, the owners in many states were often very inadequately compensated, if they were compensated at all, either by government or by private business firms upon which firms eminent-domain power was devolved under the doctrines of public use and public utilities. It was left to the courts to define the line between a taking (for which compensation must be paid) and a police power regulation (noncompensable). When the courts required compensation, the legislatures were still left with large discretionary authority to establish the formulae for determining money damages. See Freyer, "Reassessing," and Scheiber, "Property Law," note 19, supra. On a related point, see Christopher L. Tomlins, Law, Labor and Ideology in the Early American Republic 74-96 (Cambridge, UK, 1993), regarding the police power and its reach, especially with regard to property law development in the post-Revolutionary era as an instrument of conservatives to head off egalitarianism.

${ }^{21}$ Scheiber, "Road to Munn," 334-60, 390-402. A civillaw perspective on an issue central to Lord Hale's analysis of rights in waterways may be found in E. de Vattel, The Law of Nations or the Principles of Natural Law ( 1758 edition; trans. Charles G. Fenwick, Washington, DC, 1916; reprinted in the Legal Classics Library, New York, 1993).

${ }^{22}$ This element of civil-law doctrine found its way explicitly into a landmark American case in which the Court quoted Vattel as follows: "Were the state strictly to indemnify all those whose property is injured [by destruction incident to wartime operations], the public finances would soon be exhausted, and every individual in the state would be obliged to contribute his share in due proportion, a thing utterly impracticable." U.S. v. Pacific Railroad, 120 U.S. 227 (1887) 235 (Field, J., quoting Vattel, Law of Nations, Book III, c. 15, sec. 232). Later in the present study, below, the Pacific Railroad case will be considered.

${ }^{23}$ See, inter alia, Abraham D. Sofaer, War, Foreign Affairs, and Constitutional Power: The Origins (Cambridge, MA, 1976); J. S. Reeves, "The Influence of the Law of Nature Upon International Law in the United States," American Journal of International Law, 3 (1909), 547ff.; and the citations in text below of the Marshall Court cases. ${ }^{24}$ Consider, for example, the crucial influence of international law in the influential decision invalidating (under principles accepted as universal) an American naval vessel's seizure of a Spanish-flag fishing boat in offshore waters during the War with Spain, in the famous case of The
Paquette Habana, 175 U.S. 677 (1900), in which the decision stated that "[I]nternational law is part of our law, and must be ascertained and administered by the courts of justice of appropriate jurisdiction" in the absence of a treaty or "controlling executive or legislative act or judicial decision" (id., 700). The Supreme Court in earlier years had consistently adhered to the dictum of the Marshall Court in Murray v. The Charming Betsy, 2 Cranch 64, 118 (1804) (" $[\mathrm{A}] \mathrm{n}$ act of Congress ought never to be construed to violate the law of nations" unless clearly overridden by the terms of the Constitution).

${ }^{25}$ See, e.g., Harold Hongju Koh, "The Spirit of the Laws," Harvard International Law Journal, 43 (2002), 23ff.; and Michael J. Glennon, "May the President Violate Customary International Law? Can the President Do No Wrong?" American Journal of International Law, 80 (1986), $923 \mathrm{ff}$. The arguments for the need to honor emerging principles of international law have received new prominence since the $9 / 11$ attacks and the incarceration of foreign combatants and even American citizens being denied access to counsel or right to confront witnesses, or even to be advised of the specific charges against them.

${ }^{26} 6$ U.S. 170 (1804). In the case of Amelia, 1 Cranch 1 (1801) the court had found that a neutral armed vessel in possession of the French might, be lawfully captured as a matter of the war powers and the rules of international law.

${ }^{27} \mathrm{Id}$., at $178-79$.

${ }^{28}$ See Part 2, by Herbert A. Johnson, of the book by George Lee Haskins and Herbert A. Johnson, Foundations of Power: John Marshall, 1801-15 (Oliver Wendell Holmes Devise History of the Supreme Court of the United States, vol. II, New York and London, 1981). Johnson is the authoritative source on the Marshall Court's project for incorporating international law into the constitutional jurisprudence of the United States. See also the excellent brief overview and analysis in R. Kent Newmyer, John Marshall and the Heroic Age of the Supreme Court (Baton Rouge, LA, 2001), 274-91.

${ }^{29}$ See Rossiter, Constitutional Dictatorship, 143-44; and Gross, "Chaos and Rules," passim.

${ }^{30}$ See discussion of Mitchell v. Harmony, below.

${ }^{31}$ Honolulu Star-Bulletin, "No Verdict Yet," December 22, 1950 (report of charge to the jury). With Jane L. Scheiber, coauthor, the present writer is completing a book-length study of martial law in Hawaii, including analysis of the civil indemnification trials.

${ }^{32} 12$ U.S. 110 (1814).

${ }^{33}$ Id., 122-23.

${ }^{34} I d$., 119. Emphasis in original.

${ }^{35}$ Id., $145-51$.

${ }^{36}$ Koh, "Why the President (Almost) Always Wins," 1283ff., 1316-17. Koh derives his concept of a "National Security Constitution" from the formulation set forth by Jackson in his Youngstown concurrence, in Youngstown 
Sheet and Tube Co. v. Sawyer, 343 U.S. 579, 634ff. (1952) (Jackson, J., concurring). Maeva Marcus, Truman and the Steel Seizure Case: The Limits of Presidential Power (New York, 1977) is the definitive study of this case. See also text below on Youngstown in light of propertylaw/emergency-powers precedents.

3754 U.S. 115 (1852).

${ }^{38} \mathrm{Id}$., 134 (emphasis added).

${ }^{39} \mathrm{Id} ., 135$.

${ }^{40} I d$.

${ }^{41}$ It should be noted, however, that the staunch Jacksonian Justice Peter Daniel did, as he often would, dissent. In this instance, he dissented on procedural grounds, expressing his outrage that the New York trial judge should have presented the kind of instructions that left the jury little choice but to hold against Colonel Mitchell. Id., 138ff. On the Taney Court's various assertions of judicial power, together with analysis of instances in which it advocated exercise of judicial restraint, see Bernard Schwartz, From Confederation to Nation: The American Constitution, 1835-1877 (Baltimore, 1973), 23-37.

4271 U.S. 2 (1866). For a full discussion of the case and its background, see Charles Fairman, Reconstruction and Reunion, 1864-88, part 1 (The Oliver Wendell Holmes Devise History of the Supreme Court of the United States, vol. 6, New York and London, 1971); see also Neely, Fate of Liberty, 160-84.

${ }^{43}$ See John P. Frank, "Ex parte Milligan v. the Five Companies: Martial Law in Hawaii," Columbia Law Review, 44 (1944) 639.

${ }^{44} 120$ U.S. 227 (1887).

${ }^{45} 78$ U.S. 268 (1870).

${ }^{46}$ Confiscation Acts of August 6, 1861, and July 17, 1862; Phillip Shaw Paludan, "A People's Contest": The Union and Civil War, 1861-1865 (New York, 1988), 64-65, $79 \mathrm{ff} ., 208$.

${ }^{47}$ Harold M. Hyman, A More Perfect Union: The Impact of the Civil War and Reconstruction on the Constitution (New York, 1973), 177-81.

${ }^{48}$ The affidavit also stated that Miller held $\$ 109,000$ in Indiana state bonds, similarly using income thereof for support of the Confederacy. How a New York resident could have had this conversation in July 1863 , as the affidavit claimed, in the midst of the heavy fighting in the eastern section of the Confederacy was not made clear in the record, despite challenge by Miller's counsel. 78 U.S. at $276,279$.

${ }^{49}$ Miller v. United States, 78 U.S. at 291.

${ }^{50} \mathrm{Ibid}$. at 306.

${ }^{51} \mathrm{Ibid}$. at 305 .

${ }^{52}$ Quoted ibid. at 296 (emphasis added).

${ }^{53} \mathrm{Ibid}$. at 323 .

${ }^{54} \mathrm{Ibid}$. at $317-18$.

${ }^{55}$ See discussion of the Chemical Foundation case in text below.

\author{
${ }^{56} \mathrm{Ibid}$. at 306 \\ ${ }^{57} 120$ U.S. $227,229$. \\ ${ }^{58} \mathrm{Ibid}$. at $229-30$ (a detailed account of the meeting and \\ commitments made). \\ ${ }^{59} \mathrm{Ibid}$. at 234 . This issue is dealt with in the concluding \\ section below on the twentieth century. \\ ${ }^{60} \mathrm{Ibid}$. at 235 (quoting Vattel, Law of Nations). \\ ${ }^{61} \mathrm{Ibid}$. at $235-36$. \\ ${ }^{62} \mathrm{Ibid}$. at 236.
}

${ }^{63} \mathrm{Ibid}$. at 238 (quoting Grant's veto message from Congressional Globe, $42 \mathrm{~d}$ Cong., $2 \mathrm{~d}$ sess., part V, p. 4155-56).

${ }^{64}$ Field's dissent also reflected his general posture of drawing bright lines between legitimate state power and the sphere of private rights, with very full powers to be allowed the state where its authority met his standard of legitimate action. On Field's position in the 1870 s decisions and after, see the authoritative study by Charles W. McCurdy, "Justice Field and the Jurisprudence of Government-Business Relations: Some Parameters of Laissez-Faire Constitutionalism, 1863-1897," in American Law and the Constitutional Order, ed. Lawrence M. Friedman and Harry N. Scheiber (expanded ed., Cambridge, MA, 1987), 246ff.; see also Hyman, More Perfect Union, 348ff.

${ }^{65}$ See especially works by Rossiter, Lobel, Koh, Belknap, and Gross as cited in the notes, supra.

${ }^{66}$ The Lever Food Control and Fuel Act, 40 Stat. 276 (1917); Trading with the Enemy Act, 40 Stat. 411 (1917); Rossiter, Constitutional Dictatorship, 243-45. A thorough overview of the emergency administration under Wilson is in Alfred H. Kelly, Winfred A. Harbison, and Herman Belz, The American Constitution: Its Origins and Development ( 7 th ed., New York, 1991). The adjudication of suits arising from implementation of Wilson's war agencies and their regulatory regimes is analyzed fully in Christopher N. May, In the Name of War: Judicial Review and the War Powers Since 1918 (Cambridge, MA, 1989), a work of exceptional quality. My own framework and interpretations of the modern developments, as presented in this section, differ in some important respects from May's, but I want to acknowledge my special indebtedness to his work for its insights and scope of the research regarding modern war-powers jurisprudence.

${ }^{67}$ Scheiber, Wilson Administration and Civil Liberties; Paul L. Murphy, World War I and the Origin of Civil Liberties in the United States (New York, 1979); James R. Mock and Cedric Larson, Words that Won the War: The Story of the Committee on Public Information, 1917-1919 (Princeton, NJ, 1939).

68272 U.S. 1 (1926).

${ }^{69} \mathrm{Ibid}$. at 6 (quoting the corporation's charter).

${ }^{70} \mathrm{Ibid}$. at $7-8$.

${ }^{71}$ See especially Lamar v. Brown, 92 U.S. 187 (1876), and discussion of this and related cases in Roger I. Roots, "Government by Permanent Emergency: The Forgotten History of the New Deal Constitution," Suffolk University 
Law Review, 33 (2000), 259, 273ff. See also discussion of Miller, the Civil War case, supra.

${ }^{72}$ United States v. Curtiss-Wright Export Corporation, 299 U.S. 304 (1936). On this critical development, see Koh, "Why the President (Almost) Always Wins," discussing how the merger of presidential foreign-affairs power and enemy-alien property doctrine was achieved in the Dames and Moore decision. See also Walter LaFeber, "The Constitution and United States Foreign Policy," Journal of American History, 74 (1987), 695ff.; Edward S. Corwin, The President: Office and Powers, 1787-1948 (3rd ed., New York, 1948). Chapters 4-6.

${ }^{73}$ See James G. Randall, Constitutional Problems Under Lincoln (New York, 1926), chapter 3.

${ }^{74} 256$ U.S. 135 (1921).

${ }^{75}$ Chastleton Corp. v. Sinclair, 264 U.S. 543 (1924). See full discussion in May, In the Name of War, 223-53.

${ }^{76}$ Rossiter, Constitutional Dictatorship, 219.

${ }^{77}$ The phrase was used often by Edward S. Corwin.

${ }^{78}$ Franklin D. Roosevelt, On Our Way (New York, 1934), quoted in Corwin, The President: Office and Powers, 538.

${ }^{79}$ Presidential Message of September 7, 1942, quoted in Rossiter, Constitutional Dictatorship, 268.

${ }^{80}$ Walter LaFeber, "The Constitution and Foreign Policy," Journal of American History, 74 (1987), 695ff.

${ }^{81}$ See Belknap, "The New Deal"; Paul L. Murphy, The Constitution in Crisis Times, 1918-1969 (New York, 1972), 97-169; Charles W. McCurdy, "The Liberty of Contract' Regime in American Law," in The State and Freedom of Contract, ed. Harry N. Scheiber (Stanford, CA, 2000), 160, 193-97; and generally, Laurence H. Tribe, American Constitutional Law (Mineola, NY, 1978).

82290 U.S. 398 (1934).

${ }^{83} \mathrm{Ibid}$. at 425 .

${ }^{84}$ Laws of Minnesota, 1933, chapter 339, quoted in ibid. at 416 .

${ }^{85} 285$ U.S. 262 (1932).

${ }^{86} 286$ U.S. 262, 307-8.

${ }^{87}$ Noble State Bank v. Haskell, 219 US. 104, 112 (1911).

Emphasis added.

${ }^{88}$ Ibid. at 112 (citing Hudson County Water Co. v. McCarter, 209 U.S. 249, 355).

${ }^{89}$ Chastleton Corp. v. Sinclair, 264 U.S. 543 (1924); see text above on Block v. Hirsh, and see also May, In the Name of War, chapter 8 . This quest for the line between the policy power and "takings" that required compensation characterized Holmes's approach to police power more generally in the post- 1910 cases, culminating in his famous opinion in Pennsylvania Coal Co. v. Mahon, 260 U.S. 393 (1922), on which see Lawrence M. Friedman, "A Search for Seizure: Pennsylvania Coal Co. v. Mahon in Context," Law and History Review, 4 (1986), 1-23.

${ }^{90}$ The emphasis in italics of the word "crises" is as written in by Hughes himself.
${ }^{91} 290$ U.S. 398 at $442-43$.

92 Wilson v. New, 243 U.S. 332 at 348 (1917) (a unanimous decision upholding constitutionality of the federal eighthour law for railroad workers). For an insightful comment on the inadequacy of similar formulae on the problem of "necessity," see Kenneth W. Dam, "The Legal Tender Cases," The Supreme Court Review, 1981 vol., 367, 40812 (1982).

93290 U.S. at 426.

${ }^{94}$ Nebbia v. New York, 291 U.S. 502 (1934); see also Scheiber, "Road to Munn," 330-31.

${ }^{95}$ Wickard v. Filburn, 317 U.S. 111 (1942).

${ }^{96}$ See Murphy, Constitution in Crisis Times; Scheiber, "Redesigning the Architecture of Federalism," 357-65; Belknap, "The New Deal and the Emergency Powers Doctrine," 67ff.; and Barry Cushman, Rethinking the New Deal Court: The Structure of a Constitutional Revolution (New York, 1998).

${ }^{97} 343$ U.S. 579 (1952). The authoritative analysis of the case, with in-depth discussion of the background facts, contending doctrinal arguments, and the process of adjudication and decision, is in the classic study by Marcus, Truman and the Steel Seizure Case, note 36 supra. Symposium "Youngstown at Fifty," Constitutional Commentary, 19 (2002), 1-289.

${ }^{98}$ The diversity of views in the concurring opinions is discussed fully in ibid. But see also Koh's analysis in "Why the President (Almost) Always Wins," cited earlier, of Justice Jackson's analysis of the National Security Constitution.

${ }^{99}$ Argument of the Solicitor General, quoted in Marcus, Truman and the Steel Seizure Case, 170.

${ }^{100}$ Scheiber and Scheiber, "Bayonets in Paradise," 624 29.

${ }^{101}$ Irons, Justice at War, 280ff., 316-18.

${ }^{102}$ In this instance, Congress had given Truman a way to handle the threatened strike under terms of the TaftHartley Act, but he declined to invoke that statute and its provisions, preferring more direct action under the seizure policy.

${ }^{103}$ Warren, quoted in Marcus, Truman and the Steel Seizure Case, 213.

${ }^{104}$ Marcus, ibid.

${ }^{105}$ New York Times, "Report on U.S. Antiterrorism Law Alleges Violation of Civil Right," July 21, 2003, p. 1 (reporting on internal investigations by Justice Department on civil-rights and civil-liberties violations in the implementation of the USA PATRIOT Act).

${ }^{106} 343$ U.S. 579, 634-35.

${ }^{107}$ Duncan v. Kahanamoku, 327 U.S. 304, at 335, 337.

${ }^{108} 344$ U.S.149 (1952).

${ }^{109} 344$ U.S. at 153-54 (quoting 120 U.S. at 234).

${ }^{110} 344$ U.S. at 154.

${ }^{111}$ The Court also cited as precedent a decision from the Spanish-American War in which sixty-six buildings 
owned by an American mining and trading corporation were destroyed by U.S. forces in Cuba when the American commanders received information that the property might contain yellow-fever germs that would threaten their troops with the disease. The Court ruled that because the decision had been taken in good faith to assure "the health, efficiency, and safety" of forces under arms and at war, it was valid under the rules of war; the American ownership of the buildings did not serve as a basis for a claim, as they were in enemy territory and hence to be treated in law as enemy property. Juragua Iron Co., Ltd. v. U.S., 212 U.S. 297 (1909).

${ }^{112}$ And in that respect, the Court pointed out, it was distinguished from the taking of Harmony's wagon train and cargo in the Mexican War case of Mitchell v. Harmony, discussed above. 